\title{
A Mágikus Fogalomképzés Skála hazai változatának kialakítása
}

\section{RÓZSA SÁNDOR ${ }^{1,2 *}$ - VINCZE GÁBOR ${ }^{3}$ - TÖRÖK IMRE ANDRÁS ${ }^{3}$ - HUPUCZI ERNŐ ${ }^{4}$ - HARGITAI RITA ${ }^{5}$ - MARTIN LÁSZLÓ ${ }^{6}$ - HARTUNG ISTVÁN ${ }^{4}$ - TIRINGER ISTVÁN ${ }^{4}$ - SIMON MÁRIA ${ }^{7}$ - KÁLLAI JÁNOS ${ }^{4,8}$}

${ }^{1}$ Department of Psychiatry, Washington University School of Medicine, St. Louis, USA

${ }^{2}$ Károli Gáspár Református Egyetem, Bölcsészet és Társadalomtudományi Kar, Pszichológiai Intézet, Budapest

${ }^{3}$ Békés Megyei Központi Kórház Pándy Kálmán Tagkórháza, Pszichiátriai Osztály, Gyula

${ }^{4}$ Pécsi Tudományegyetem, Általános Orvostudományi Kar, Magatartástudományi Intézet, Pécs

${ }^{5}$ Pázmány Péter Katolikus Egyetem Pszichológiai Intézet, Budapest

${ }^{6}$ Kaposvári Egyetem, Pedagógiai és Pszichológiai Intézet, Kaposvár

${ }^{7}$ Pécsi Tudományegyetem, Pszichiátriai és Pszichoterápiás Klinika, Pécs

${ }^{8}$ Pécsi Tudományegyetem, Bölcsészettudományi Kar, Pszichológiai Intézet, Pécs

(Beérkezett: 2020. január 1.; elfogadva: 2020. szeptember 23.)

Háttér: A pszichózisra való sérülékenység feltárása és a korai intervenció a klinikai gyakorlat és a kutatások fontos részét képezik. A Mágikus Fogalomképzés Skála az egyik leggyakrabban alkalmazott önjellemzó kérdőív, amelyet a pszichózisra való hajlam feltárására dolgoztak ki. Meglepó azonban, hogy a Mágikus Fogalomképzés Skála pszichometriai jellemzőit klinikai mintán szinte alig vizsgálták. Célkitüzés: A tanulmány fő célja a Mágikus Fogalomképzés Skála faktorszerkezetének feltárása nagy elemszámú egyetemi hallgatói mintán $(n=1730)$ és pszichiátriai betegek $(n=319)$ körében. Módszerek: A kérdőív faktorszerkezetét megerősítő (egydimenziós, többdimenziós szerkezet, bifaktoros elrendezés) és feltáró faktorelemzések, valamint parallel-elemzések segítségével vizsgáltuk. A skálák megbízhatóságát a hagyományos módszerek mellett (pl. Cronbach- $\alpha$ ) modellalapú megbízhatósági becslésekkel (hierarchikus ómega) is jellemeztük. A faktorszerkezet elemzését követóen a valószínúségi tesztelméleti alapokon nyugvó Tétel-válasz elmélet (Item Response Theory, IRT) segítségével az item-paraméterek becslését (nehézség és diszkrimináció) és az eltérő tételmúködést is megvizsgáltuk, majd egy rövid, 15 tételes változatot alakítottunk ki, amelynek a kritériumvaliditását más mérőeszközök felhaszná-

\footnotetext{
* Levelező szerző: Rózsa Sándor, Károli Gáspár Református Egyetem, Bölcsészet és Társadalomtudományi Kar, Pszichológiai Intézet, Budapest, 1037, Bécsi út 324. E-mail: rozsa.sandor@kre.hu
} 
lásával teszteltük (pl. Szkizotípia Személyiség Kérdőív rövid változat; Davis-féle Empátia Kérdőív). Eredmények: A parallel-elemzés a hallgatói mintán 3 faktort, míg a klinikai mintán 2 dimenziót valószínúsített. Mindkét minta esetében a negatív tételek önálló dimenziót alkottak, amit járulékos faktornak tekintetve a későbbiekben nem elemeztünk. A megerősítő faktorelemzés a normatív hallgatói mintán a bifaktoros struktúrát támasztotta alá, ahol az általános faktor mellett két speciális dimenzió jelent meg: paranormális hiedelmek és mágikus okság/spiritualitás (RMSEA =0,052; CFI = 0,993; TLI =0,990). A klinikai mintán az egydimenziós szerkezet adta a legjobb illeszkedési mutatókat (RMSEA = 0,032; CFI $=0,970$; TLI = 0,965). A 15 tételre rövidített skála jó pszichometriai jellemzőkkel rendelkezett, bár az IRT elemzés rávilágított arra, hogy néhány tétel eltéró jelentést hordoz a nemek (nők vs. férfiak) vagy a vizsgálati minta típusa (normatív vs. klinikai) szerinti összevetéskor. Következtetések: Eredményeink megerősítik, hogy a mágikus fogalomalkotás a klinikai mintán egydimenziós modellel ragadható meg leginkább, ezzel szemben a normatív hallgatói mintán már inkább egy bifaktoros struktúra valószínúsíthető, amelynek két speciális dimenziója az adaptív (mágikus okság/spiritulaitás) és maladaptív (paranormális hiedelmek) sajátosságok mentén különül el.

Kulcsszavak: Mágikus Fogalomalkotás Skála, mágikus gondolkodás; paranormális hiedelmek, feltáró és megerősítő faktorelemzés, bifaktoros modell, adaptív és maladaptív funkciók

\section{Bevezetés}

A kognitív fejlődést meghatározó mágikus gondolkodásmód a gyermekkort követó időszakban, a múveleti gondoldás megjelenésével fokozatosan veszít a jelentőségéből, de felnőttkorban is fontos szerepet tölt be. A mágikus valóságszemlélet a felnőtt realitáskoncepció kiinduló pontja (Piaget, 1957; Woolley, 2000).

A következőkben röviden ismertetjük a mágikus gondolkodásmód főbb jellemzőit. (1) A szinkretikus sémákba rendezett környezetben a személy gondolatai egocentrikusak, mindenhatók, mellőzik a mindennapi vélekedésekben szereplő kritikus tapasztalatokat, a szemlélet megköti a gondolkodást. A gondolat és a cselekedet ennek következtében egybeolvad. A gondolat és a cselekvés között nincs határ, a kontrollképesség elenyésző (Shafran \& Rachman, 2004). Hasonló mechanizmus múködik felnőttkorban a kényszergondolatok, a szerszerhasználat, vagy a játékszenvedély kialakulásakor. Gyenge a kontroll a gondolat és cselekedet összeillesztésére. A végrehajtó funkciókból pedig hiányzik a konvenciókhoz kötött logikai elemzéshez szükséges késleltetésképesség. (2) A mágikus gondolkodás a valós világ téri és idői szerkezetének felfüggesztését eredményezi. A vágy és a fantázia figyelmen kívül hagyja a reális körülményeket. A személy úgy gondolja, hogy az akarat erejével, figyelem-összpontosítással gondolatátvitellel, ráolvasással, szelle- 
mi úton gyakorolt erő átadásával, vagy szellemi úton való fizikai forma megváltoztatásán keresztül a kitǔzött cél konkrét cselekvés nélkül is elérhető. Úgy, ahogy ez az álomban rendszeresen megtörténik. Részben megváltozott tudatállapot, amely nem szembesül a fizikai törvények és a társas szabályok létezésével (Subbotsky, 2010). (3) Az élettelen tárgyaknak, fizikai jelenségeknek, növényeknek akarat- és szándéktulajdonítása (pl. haragszik az ég), az élettelen világ emberi szociális szokás- és kapcsolatrendszerébe való bevonása, és az ezen keresztül végzett kontrollképesség gyakorlása, totem, kabbalisztikus tevékenység, embert helyettesító, életre kelthető másolatok létezésével kapcsolatos gondolatok gerjesztése, akaratot közvetítő tárgyak, ellenségek legyőzését segítő misztikus erőt közvetítő ábrák, eszközök készítése, biztonságot fokozó rituálékba való bevonása. Bizonytalan helyzetekkel, félelmekkel kapcsolatos repetitív cselekedetek, rumináció, és közömbösítő rituálék (Piaget, 1957; Subbotsky, 2010).

Felnőtteknél a mágikus gondolkodásmód jeleit szkizofrénia spektrumzavarok jelenléte esetében, elsősorban a pozitív tünetek megjelenésekor is megtalálhatjuk (Chapman, Chapman, Kwapil, Eckblad, \& Zinser, 1994; Claridge, 1997; Hanssen és mtsai, 2003; Kelleher és mtsai, 2012). Egészséges személyek körében és szubklinikus eseteknél a mágikus gondolkodás a kreatív múvészeti alkotások és az eredeti tudományos gondolatok alapvető kellékeként vehetők számba. Alvászavarokkal, agyfélteke- és kézhasználati preferenciákkal való összefüggése alapján feltételezhetően genetikus tényezők is részt vesznek a mágikus gondolkodás fennmaradásában (Acar \& Sen, 2013; Elek és mtsai, 2020; Fejes, Rózsa, \& Must, 2018; Grant, Green, \& Mason, 2018; Polner, Simor, \& Kéri, 2018).

A mágikus gondolkodás által konstruált realitás szubjektív és vágyvezérelt. Az én stabilitásának megőrzését ellátó funkciókban a 3-6 éves korú gyermekre jellemző formák a meghatározók. Hátrányos fejlődési környezetben, társas támogatás zavarai esetében a mágikus gondolkodásmód felerősíti a pszichopatológiai tünetek intenzitását, és szinkretikus sémákat (a különböző benyomások egyetlen egységbe történő kapcsolódása) felszínre hozó regresszív természetú kognitív zavarokat idéznek elő (Miller \& Ellen-Miller, 1989; Werner, 1948). Ugyanakkor felnőttkorban, megfelelő pozitív támogató légkörben, a mágikus gondolkodás elősegíti a proszociális képességek fejlődését és a társkapcsolatok elmélyülését (Niemyjska, 2015). A társas adaptáció és a pszichopatológiai tünetek formájában megmutatkozó adaptációs zavarok alakulásában a mágikus gondolkodás ellentmondásos szerepet játszik. A felvetett kettősség indokolja a mágikus gondolkodásmód megbízható eszközökkel történő felmérését, szerepének részletesebb elemzését, és az adaptív és maladaptív hatások elkülönítését. 


\subsection{A Mágikus Fogalomképzés Skála kidolgozása és pszichometriai jellemzői}

A terület egyik legismertebb és leggyakrabban alkalmazott önjellemzős méróeszközét, a Mágikus Fogalomképzés Skálát (Magical Ideation Scale), Eckblad és Chapman (1983) dolgozta ki. A 30 tételes kérdőív a mágikus és szokatlan szenzoros jelenségek, a babonák és hiedelmek széles körét öleli fel. A szerzők a mágikus gondolkodást az oksági kapcsolatok elfogadásának olyan tendenciájaként jellemezték, amely az adott kultúrát alapul véve nem tekinthető érvényesnek (pl. gondolatátvitel, irracionális hiedelmek). A tételek megalkotására az 1970-es évek népszerú szkizotípia elméletei voltak hatással (pl. Meehl, 1962; Rado, 1953). Meehl (1964) például a kutatások és a klinikai gyakorlat számára részletes vonás- és tünetlistát készített a szkizotíp jellemzókről, amelyekre Eckblad és Chapman is nagyban támaszkodott. A tételszelekciók fóként korrelációs vizsgálatok eredményein alapultak, így az előzetesen kialakított mágikus fogalomképzés skála tételeit olyanokkal bővítették, amelyek jelentősen korrelálnak a meglévőkkel, és viszonylag alacsony együttjárást mutatnak a szociális kívánatossággal, valamint a szkizotípia más aspektusait mérő skálákkal. A szerzők az 1970-es években a Wisconsin Szkizotípia Skálákat ${ }^{1}$ (amelynek része a Mágikus Fogalomképzés Skála) évről évre több ezer fős mintákon, elsóéves egyetemi hallgatók körében töltették ki, akik közül két év elteltével a szélsőségesen magas értékeket elérő diákokat ismételten felmérték. Az eredmények azt mutatták, hogy a Mágikus Fogalomképzés Skálán magas pontszámot elérő diákok esetében a késóbbiekben gyakorta megjelentek szkizotíp vonások és a pszichotikus esetekre jellemzó tünetek (Chapman \& Chapman, 1987).

A nemzetközi kutatási eredmények alapján a Mágikus Fogalomképzés Skála belső konzisztenciája és az időbeli stabilitása elfogadható. A Cronbach- $\alpha$ mutató értéke több vizsgálatai eredmény alapján 0,79 és 0,90 között ingadozott, míg a teszt-reteszt korreláció értéke 0,73 és 0,79 közötti volt (Chapman, Chapman, \& Miller, 1982; Garzitto és mtsai, 2016; Kingdon,

\footnotetext{
1 A Wisconsin Szkizotípia Skálákat az alábbi négy vonás megragadására dolgozták ki: a testérzékelés torzulása (pl. tisztázatlan testhatárok, a testi idegenség érzése, a testrészek méretében és arányaiban történó torzult észlelések), testi anhedónia (a tipikusan kellemes testi ingerek megélésének nehézsége: pl. táplálkozás, szex), szociális anhedónia (a társas kapcsolatokból származó öröm átélésének nehézsége: pl. beszélgetés, közös élmények) és mágikus fogalomképzés. A Wisconsin Szkizotípia Skálák négy önjellemző skálája: Perceptuális Aberráció Skála (Perceptual Aberration Scale; Chapman és mtsai, 1978), Testi Anhedónia Skála (Physical Anhedonia Scale; Chapman és mtsai, 1976), Módositott Szociális Anhedónia Skála (Revised Social Anhedonia Scale; Eckblad és mtsai, 1982) és Mágikus Fogalomképzés Skála (Magical Ideation Scale; Eckblad \& Chapman, 1983). A fenti skálák közül az első háromnak egyelőre nincs magyar nyelvú változata.
} 
Egan, \& Rees, 2011; Winterstein, Ackerman, Silvia, \& Kwapil, 2011a; Winterstein és mtsai, 2011b; Winterstein, Willse, Kwapil, \& Silvia, 2010).

A Wisconsin Szkizotípia Skálák érvényességét (konstruktum, konvergens és divergens validitását) számos kutatási eredmény támasztja alá (pl. Chapman, Chapman, \& Kwapil, 1995; Edell, 1995; Fonseca-Pedrero és mtsai, 2008; Graves \& Weinstein, 2004; Kwapil, Barrantes-Vidal, \& Silvia, 2008; Lewandowski és mtsai, 2006; Ross, Lutz, \& Bailley, 2002). A szkizotíp vonást olyan multidimenzionális konstruktumnak tekintik, amely egyfajta genetikai sérülékenységet jelent a szkizofrénia spektrum zavar későbbi kibontakozására. Meehl (1962) ezt a sérülékenységet, sebezhetőséget szkizotaxiának nevezte, amelynek jelenléte szükséges, de önmagában nem elegendő feltétele a szkizofrénia kifejlődésének. A Wisconsin Szkizotípia Skálákkal végzett utánkövetéses vizsgálatok eredményei meggyőzően támasztották alá a skálák bejósló erejét, prediktív érvényességét (pl. Chapman és mtsai, 1994; Flückiger és mtsai, 2016; Gooding, Kwapil, 1998; Kwapil és mtsai, 2013; Miettunen és mtsai, 2011; Shah és mtsai, 2012; Tallent, \& Matts, 2005;).

A Mágikus Fogalomképzés Skálát számos nyelvre lefordították, többek között franciára (Dumas és mtsai, 2000), litvánra (Utināns, 2015), németre (Scherbarth-Roschmann \& Hautzinger, 1991), olaszra (Garzitto és mtsai, 2016), perzsára (Khoshouei, 2008), portugálra (Vieira, Villemor-Amaral, \& Pianowski, 2016), spanyolra (Fonseca-Pedrero és mtsai, 2009), törökre (Çam, Seydooğulları, \& Artar, 2014). A kutatásokban és a klinikai gyakorlatban egyaránt népszerú skálát a legkülönfélébb mintákon alkalmazták: például serdülők (Garzitto és mtsai, 2016), koponyasérültek (Zhong, Krueger, Wilson, Bulbulia, \& Grafman, 2018), valamint kényszeres zavarban (Einstein \& Menzies, 2004; West \& Willner, 2011), szkizofrénia spektrum zavarban (Lyons és mtsai, 1995; Stip és mtsai, 2007), evészavarban (Lavender, Shubert, Silva, \& Treasure, 2006), illetve szklerózis multiplexben (Te Wildt \& Schultz-Venrath, 2004) szenvedők körében.

Mivel a skálát a szerzők egydimenziós mérőeszközként mutatták be, így a későbbiekben viszonylag kevés olyan tanulmány jelent meg, amely a 30 tételes méróeszköz dimenzionalitását vizsgálta volna. A kapott eredmények meglehetősen ellentmondásosak, mivel eltérő elemszámú mintákon és különféle módszerekkel történtek az elemzések (1. táblázat). Az áttekintő táblázat adatai alapján szembeötlő, hogy tételenkénti faktorelemzést csak egyetemi hallgatói, illetve általános és középiskolás mintán végeztek. A feltáró faktorelemzésekkel (EFA) végzett eredmények (fókomponens [PCA] és fótengelyelemzés [PAF]) három esetben az egydimenziós szerkezetet ugyan alátámasztják, de látható, hogy az egyetlen faktor az összvariancia igen csekély hányadát magyarázza: 20-29,6\%. Két további feltáró faktorelemzés (PAF és PCA ferde forgatás) két-, illetve háromfaktoros megoldást valószí- 
núsít. Horan, Blanchard, Gangestad és Kwapil (2004) a 30 tételból 10-et elhagyva kapták a kétfaktoros struktúrát, amelyet Paranormális hiedelmeknek és Deperszonalizációnak neveztek el. Khoshouei (2008) iráni egyetemi hallgatókon végzett fókomponens-elemzéssel háromfaktoros struktúrát valószínúsített: 1. Hallucinációs élmények és téveszmékhez hasonló hiedelmek, 2. Telepátia, 3. Paranormális hiedelmek. A három megerősítő faktorelemzésből (CFA) kettő esetében az illeszkedési mutatók elfogadhatóak voltak, vagyis az adatok megfeleltek az elvárt egydimenziós struktúrának, bár néhány tétel faktorsúlya alacsony volt. Cicero és munkatársai (2019) közleményükben a 30 tételes teljes és a 15 tételes rövid változat részletes pszichometriai elemzését készítették el nagy létszámú egyetemi hallgatói mintán $(n=2312)$. Eredményeik szerint a 30 tételes változat nem egydimenziós, amit nemcsak a megerősítő faktorelemzés, hanem a modern valószínúségi tesztelméleten (Item Response Theory, IRT) alapuló tételelemzés eredménye is alátámaszt. Ezzel szemben az eredetileg Winterstein és munkatársai (2011ab) által kialakított 15 tételes rövidített változatot már egydimenziósnak találták (Cicero, Martin, \& Krieg, 2019).

\subsection{A tanulmány célkitúzése}

A mágikus gondolatok leggyakrabban alkalmazott önjellemző kérdőíve több mint 30 évvel ezelőtt készült, de a Wisconsin Szkizotípia Skálákat a mai napig a szkizotípia alapvető önjellemző mérőeszközeiként tartják számon. A skála kidolgozása során az 1970-es évek népszerú elméleti megközelítéseit alkalmazták, és a tételek kiválasztása fóként korrelációs elven alapult. A tesztfejlesztés során a szerzők elsődleges szempontja az volt, hogy a skála minél jobb bejóslást adjon a későbbi szkizofrénia spektrum zavar megjelenésére. A skála pszichometriai tulajdonságaival foglalkozó későbbi kutatások fóként a 30 tételból álló skála kiváló belső konzisztenciáját jelezték (pl. Çam és mtsai, 2014; Cicero és mtsai, 2019; Garzitto és mtsai, 2016; Johnston, 1991; Winterstein, Ackerman, Silvia, \& Kwapil, 2011a; Winterstein és mtsai, 2011b; Winterstein, Willse, Kwapil, \& Silvia, 2010), ami a tételek nagy számának köszönhetően el is várható. A skála faktorelemzésére irányuló kutatási eredmények azonban változatosak, így nehéz eldönteni, hogy a konstruktum egy vagy inkább több dimenzióval jellemezhető. A dimenzionalitás kérdése a gyakorlati felhasználás (pl. pontozás) és az elemzések szempontjából ${ }^{2}$ (pl. reliabilitásbecslés, modern valószínúségi tesztelméleten alapuló elemzések) egyaránt fontos.

2 A hagyományosan alkalmazott Cronbach- $\alpha$ mutatók vagy a valószínúségi tesztelméleten nyugvó tétel-válasz-elmélet (Item Response Theory, IRT; itemjelleggörbék, tételtorzítások vizsgálata) alkalmazásának előfeltétele a skála egydimenziós szerkezete. 


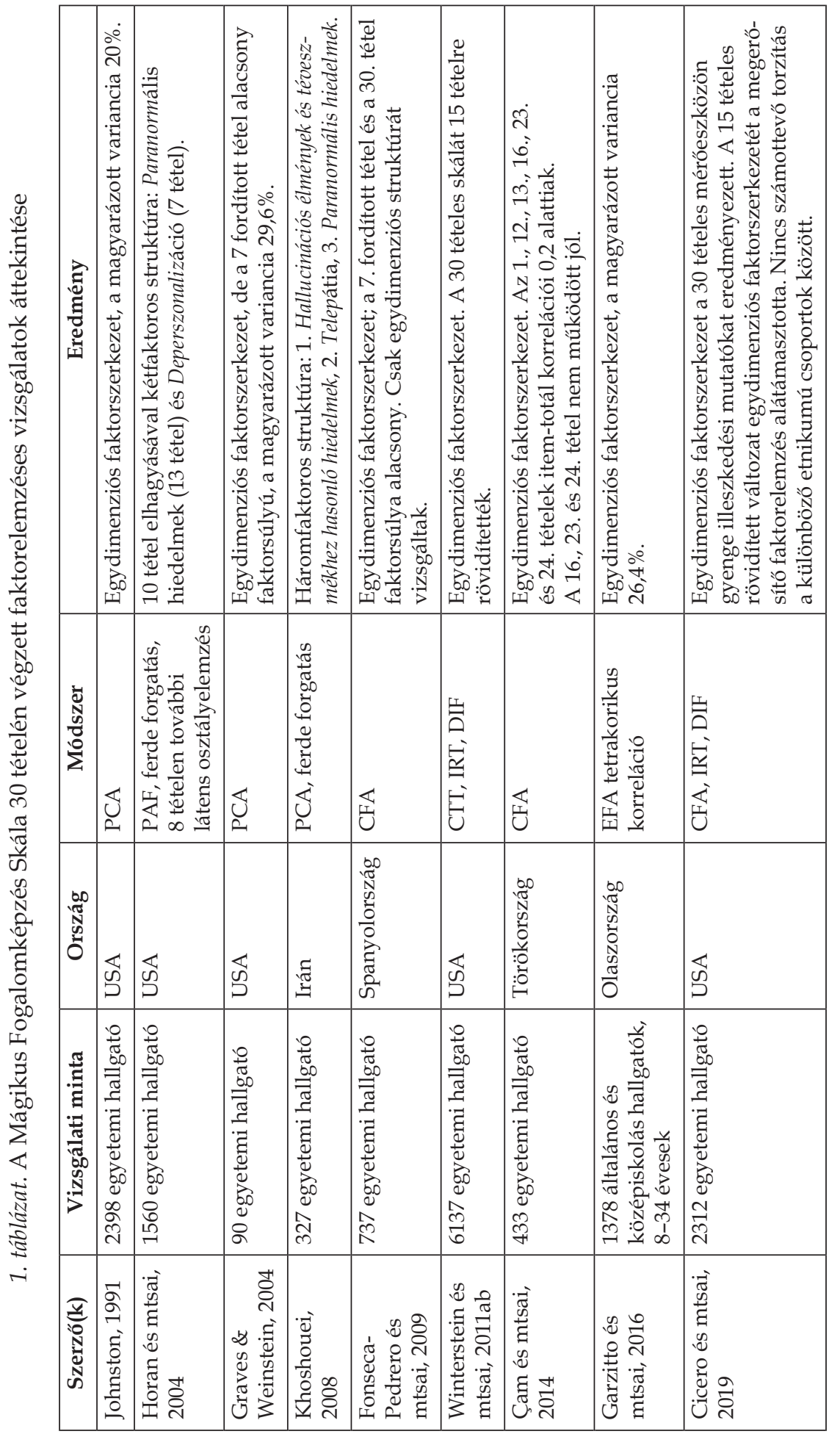

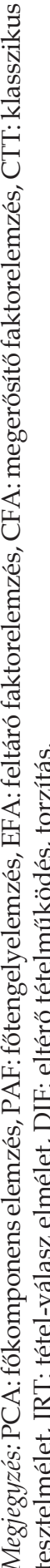


A jelen vizsgálatunk elsődleges célja a Mágikus Fogalomképzés Skála átfogó pszichometriai elemzése, amely kiterjed a 30 tételes skála faktorszerkezetének részletes vizsgálatára, a tételek belső konzisztenciájának elemzésére, a skála kritérium és konstruktum validitásának vizsgálatára, illetve a tételek modern valószínúségi tesztelméleten nyugvó elemzésére.

Tanulmányunk fontosságát nemcsak a nagy elemszámú normatív vizsgálati mintán történő elemzés jelenti, hanem az is, hogy elsóként vállalkozik klinikai mintán történő faktorelemzésre. Meglepő módon a skála részletes pszichometriai vizsgálatára klinikai mintán mindezidáig nem került sor, annak ellenére, hogy sokan a skálát elsődlegesen klinikai mérőeszköznek tartják. A fentiekből fakad vizsgálatunk további fontos célkitǔzése: annak vizsgálata, hogy az önjellemző méróeszköz tételei mennyire hordoznak eltérő jelentést a normatív és a klinikai mintába tartozó személyek, és a nemek (nők és férfiak) számára. További célkitúzésünk, hogy egy olyan hazai változatot alakítsunk ki, amely normál és klinikai mintán is egyaránt alkalmazható, emellett a modern pszichometriai kritériumoknak is megfelel.

Az elemzéseink során alkalmazott módszerek megválasztásának szempontjait és a kapott eredményeket igyekszünk részletesen kifejteni, hogy ezáltal segítsük a hazai tesztadaptációs kutatásokat.

\section{Módszer}

\subsection{Vizsgálati személyek}

A vizsgálatban 1730 egyetemi hallgató vett részt, akik egy budapesti, valamint a kaposvári és a pécsi egyetem különböző karain tanulnak nappali vagy levelező képzés keretében ${ }^{3}$. A hallgatók túlnyomó többsége nő volt (1170 fó, 67,6\%), 8 személy pedig nem jelölte meg a nemét. Az önkéntes kitöltók életkora, a levelező képzésben résztvevő hallgatóknak köszönhetően, tág tartományban szórt: az átlagéletkor 28,1 év, a szórás (SD) pedig 10,4 év. A legfiatalabb kitöltő 18 éves, míg a legidősebb 75 éves volt. A kérdőíves kitöltésekre csoportosan, az órák keretében került sor, több más önjellemző kérdőív felhasználásával. ${ }^{4}$

3 A kutatásba a Pécsi Tudományegyetem Általános Orvostudományi Karának orvostan hallgatói, a Kaposvári Egyetem Pedagógiai és Pszichológiai intézetének és a Pázmány Péter Katolikus Egyetem bölcsészhallgatói vettek részt.

4 Jelen tanulmányunkban elsődlegesen a Mágikus Fogalomképzés Skála elemzésének eredményeit szemléltetjük, más módszerekkel történő összevetésre a terjedelem korlátok miatt nem vállalkozunk. 
A klinikai mintát 319 (239 nő és 80 férfi) pszichiátriai kezelésben részesülő páciens alkotta, akik a Békés Megyei Központi Kórház Pándy Kálmán Tagkórházának Pszichiátriai Osztályán kerültek ellátásra. A betegek hangulat-, szorongásos- vagy szkizofrénia spektrum zavar diagnózissal rendelkeztek. A neurokognitív deficit és a pszichoaktív szerhasználat kizáró kritériumként szerepelt. A páciensek átlagéletkora 44,2 év volt (SD = 12,1 év), a legfiatalabb kitöltő 18, míg a legidősebb 70 éves volt.

A normatív és a klinikai mintán történő vizsgálat a Helsinki deklaráció szellemében a Pécsi Tudományegyetem Regionális Kutatásetikai Bizottságának engedélye alapján zajlott (az engedély száma: 6732 PTE/2017).

\subsection{Mérőeszközök}

Mágikus Fogalomképzés Skála: a 30 tételes önjellemző skála állításait dichotóm (igen-nem) válaszlehetőségek mentén ítélheti meg a kitöltő. A pontozás során az igen válaszok kapnak 1 pontot, míg a nem válaszok 0 -át. Kivételt képez a 7 fordított tétel, amelyeknél a nem válasz ér 1 pontot. A skálán elért magasabb pontszámok a mágikus gondolkodásmód fokozott megjelenésére utalnak. A korábbiakban már utaltunk rá, hogy a skála belső konzisztenciája és az idóbeli stabilitása elfogadható, a Cronbach- $\alpha$ mutató értéke több vizsgálati eredmény alapján 0,79 és 0,90 között ingadozott, míg a teszt-reteszt korreláció értéke 0,73 és 0,79 közötti volt (Chapman és mtsai, 1982; Garzitto és mtsai, 2016; Kingdon és mtsai, 2011; Winterstein és mtsai, 2010, 2011). A skála magyar nyelvre történő fordítását a területet jól ismerő szakember készítette, a fordítást pedig a kutatócsoport tagjai ellenőrizték, majd véglegesítették. A kérdőív megtalálható a Függelékben.

A Szkizotípia Személyiség Kérdöívet (Schizotypy Personality Questionnaire - Brief Revised, SPQ-BR; Cohen, Matthewa, Najolia, \& Brown, 2010; magyar változat: Kállai és mtsai, 2018) a DSM-5 (American Psychiatric Association, 2013) diagnosztikai rendszerben szereplő szkizotípiás személyiségzavar pontosabb diagnosztikája és a szkizofréniára jellemző tünetek iránt fokozott vulnerabilitással rendelkezők azonosítása érdekében dolgozták ki. Az SPQBR 32 állítást tartalmazó ötfokozatú Likert-skálás kérdőív (egyáltalán nem [0] - nagyon gyakran [5]) 3 főskálára és 7 alskálára bontható. A 7 alskála a következő: Gyanakvás (pl. Érzi néha úgy, hogy más emberek Önről beszélnek?), Közeli barátok hiánya (pl. Érzi úgy, hogy nem tud közel kerülni másokhoz?), Furcsa viselkedés (pl. Mások kissé különcnek, furcsának tartanak.), Szociális szorongás (pl. Gyakran érzi magát idegesnek, amikor ismeretlen emberek csoportjában találja magát?), Mágikus gondolkodás (pl. Hisz a telepátiában (gondolatolvasásban)?), Furcsa beszéd (pl. Beszéd közben gyakran egyik témáról gyorsan másikra váltok.), Szokatlan élmények iránti von- 
zalom (pl. Gyakran hallok egy hangot, ami a gondolataimat mondja ki hangosan.). Az alskálákon elért magasabb pontszám az adott jellemzó fokozott megjelenését jelzi. A 3 főskála a következő: I. Pozitív tünetek: kognitív és perceptuális zavarok; II. Negatív tünetek: az interperszonális magatartás deficitjére utalnak; III. Dezorganizált viselkedés. A szakirodalmi adatok alapján valamennyi alskála belső konzisztenciája jó, a Cronbach- $\alpha$ mutató értékei 0,90 és 0,80 közöttiek (Cohen és mtsai, 2010). A kérdőív hazai változata szintén jó pszichometriai tulajdonságokkal rendelkezik (Kállai és mtsai, 2018).

Tellegen Abszorpciós Skála (Tellegen Absorption Scale, TAS; Tellegen \& Atkinson, 1974; magyar változat: Simor, Köteles, \& Bódizs, 2011): a jelen vizsgálatban a hazai alkalmazás során bemért 5 válaszalternatívát (egyáltalán nem jellemző [1] - teljesen jellemző [5]) kínáló Likert-skálás verziót alkalmaztuk (Rózsa és mtsai, 2019), amelyben a magasabb pontszám fokozott pszichológiai abszorpciót jelez. Az abszorpciós képességet a külső és belső ingerekre vonatkozó fokozott érzékenység és az élményekben való teljes elmerülés jellemzi, amely szerepet játszik a múvészi kifejező- és befogadóképességben, a hipnózis iránti fogékonyságban, a szokatlan - esetenként mágikus, spirituális - élmények iránti befogadókészségben, és a genetikai prediszpozícók kibontakoztatásában. A kérdőív nem tartalmaz fordított tételt. Néhány példa a kérdőív tételeire: Néha kilépek a szokásos énemból és a lét teljesen más állapotát élem át.; A naplemente nagy hatással van rám.; Ha filmet, tv-t vagy egy színdarabot nézek, annyira bele tudok merülni, hogy egészen elfeledkezem magamról és környezetemről, és úgy élem át a történetet, mintha az valós lenne és én is részt vennék benne. A skálán elért magasabb pontszám a fokozott abszorpcióra utal. Tellegen (1982) kiváló belső konzisztenciáról (Cronbach- $\alpha$ : 0,88) és magas teszt-reteszt $(0,91)$ megbízhatóságról számol be egyetemi hallgatói mintán. A kiváló teszt-reteszt reliabilitást más szerző tanulmánya is alátámasztja (Kihlstrom és mtsai, 1989). A mérőeszköz kiváló megbízhatóságát és érvényességét a hazai vizsgálatok is alátámasztják (pl. Simor és mtsai, 2011; Rózsa és mtsai, 2019).

A Davis-féle Empátia Kérdőív (Interpersonal Reactivity Index - IRI; Davis, 1983; magyar fordítás: Kulcsár, 2002) az empátia egyéni különbségeinek mérésére kialakított 28 tételes mérőeszköz. A kitöltőnek 5-fokú Likertskálán kell jelölnie, hogy az egyes állítások milyen mértékben jellemzőek rá (egyáltalán nem jellemző [0] - teljes mértékben jellemző [4]). Nyolc tétel fordított pontozású. A kérdőív tételei négy, egymástól jól elkülönülő skálára bonthatók: Fantázia (pl. Nagyon magukkal ragadnak egy regény szereplőinek érzései.), Empátiás törődés (pl. Gyakran érzek törődést és aggodalmat azok iránt, akik szerencsétlenebbek nálam.), Személyes distressz (pl. Vészhelyzetben igen nyugtalannak érzem magam, feszengek.) és Nézőpontváltás (pl. Néha megpróbálom jobban megérteni a barátaimat úgy, hogy elkép- 
zelem, hogyan látszódnak a dolgok az ő nézőpontjukból.). A skálákon elért magasabb pontszám az adott jellemző fokozott megjelenését jelzi. A 7 tételból álló skálák belső konzisztenciáját becslő Cronbach- $\alpha$ mutatók értékei Davis (1983) vizsgálatainak eredményei alapján 0,70 és 0,78 közöttiek, a skálák teszt-reteszt reliabilitása pedig 0,61 és 0,81 között mozog. A mérőeszköz faktoranalitikus vizsgálatai alapján további másodrendú faktorokat azonosítottak, így a 4 skála mellett megkülönböztethetünk kognitív és affektív empátia dimenziókat is. A Kognitív empátiát a Nézőpontváltás és a Fantázia skála összegzése adja, míg az Affektív Empátia az Empátiás törődés és Személyes distressz összeadásával képezhető (Smith, 2006). Bár a kérdőívet már számos hazai vizsgálatban alkalmazták, az átfogó adaptációja egyelőre nem történt meg.

\subsection{Adatelemzési módszerek és stratégia}

A Mágikus Fogalomképzés Skála dichotóm válaszformátumú adatait a normatív és klinikai mintán hasonló módon, párhuzamosan vizsgáltuk. Elsőként a tételek egy- és többváltozós normalitását ellenőriztük, mivel ennek eredménye meghatározza a faktorelemzésnél alkalmazott becslési módszert. Ezt követően parallel-elemzést és feltáró faktorelemzést végeztünk, hogy a lehetséges dimenziók számát meghatározzuk és a tételek dimenziókba szerveződését ellenórizzük.

A Horn (1965) által bevezetett parallel-elemzés egy olyan szimulációs módszer, amely lehetőséget ad arra, hogy csak a szignifikáns főkomponenseket tartsuk meg. Az eljárás az eredeti vizsgálati minta fő paraméterei alapján (pl. mintaelemszám, változók száma) véletlenszerú mintákat képez, nem korreláló változókkal, és az így kapott sajátértékeket veti össze a vizsgálati mintán nyert korrelációs mátrix alapján kapott sajátértékekkel. Csak azokat a dimenziókat tartjuk szignifikánsnak, amelyek sajátértéke nagyobb, mint a random, korrelálatlan változókból képzett sajátérték. A módszer elve tehát az, hogy a minta variabilitása véletlenszerúen is eredményezhet 1-nél nagyobb sajátértékú komponenseket, még akkor is, ha valójában a változóink nem korrelálnak, és így előfordulhat, hogy egy 1-nél nagyobb sajátértékkel rendelkező dimenzió valójában nem képvisel valódi, értelmezhető információt.

A feltáró faktorelemzések után megerősítő faktoranalízist alkalmaztunk, hogy a feltárt struktúrát ellenőrizzük. Mivel a normatív mintánk elemszáma nagy, így a teljes mintát véletlenszerúen kettéválasztottuk, és az egyik felén a feltáró elemzéseket készítettük el, míg a másikon a megerősító elemzéseket. A két független mintán történő elemzések pontosabb, megbízhatóbb eredményeket adnak. A megerősítő faktorelemzések során az adatok 
és a teoretikus modell egybeesésének mértékét jelző illeszkedési mutatóknál a módszertani ajánlásokban megfogalmazott kritériumokat használjuk (pl. Anderson \& Gerbing, 1984; Bentler, 1990; Cole, 1987; Marsh, Balla, \& McDonald, 1988; Tanaka, 1993). Általánosan elfogadott és ajánlott, hogy a modell illeszkedésének jóságát több kritérium alapján ítéljük meg. Az egyik leggyakrabban használt illeszkedési mutató a $\chi^{2}$-próba mértéke, amelyet általában akkor tekinthetünk elfogadhatónak, ha a szabadságfokhoz viszonyított értéke alacsony (pl. kisebb, mint a szabadságfok kétszerese) és nem szignifikáns $(p>0,05)$. Ennek a mutatónak azonban több korlátja létezik. A legjellemzőbbek a többváltozós normalitás sérülésére és a mintanagyságra való érzékenység. Számos empirikus eredmény és szimulációs vizsgálat támasztja alá, hogy a normalitás sérülésekor vagy nagy elemszámú minta esetében a $\chi^{2}$-próba kevésbé informatív, és a legtöbb esetben a modell elvetését jelzi (Bentler \& Bonnet, 1980; Jöreskog \& Sörbom, 1993; McIntosh, 2006; Ropovik, 2015). A mintanagyságból fakadó korlátot gyakran a $\chi^{2}-$ próba szabadságfokhoz mért arányával próbálják kompenzálni $\left(\chi^{2} /\right.$ szabadságfok), amelynek ugyan nincs pontos kritériuma, de az ajánlások általában 2-től 5-ig terjednek, és a határérték alatti érték jelez megfelelő illeszkedést (Tabachnick \& Fidell, 2007; Wheaton, Muthen, Alwin, \& Summers, 1977).

Elemzéseink során a $\chi^{2}$ mutató mellett az alábbi illeszkedési mutatókat vesszük figyelembe: összehasonlító illeszkedési mutató (Comparative Fit Index, CFI), Tucker-Lewis-féle Illeszkedési mutató (Tucker-Lewis Nonnormed Fit Index, TLI; Tucker \& Lewis, 1973), valamint a becslési hiba négyzetes átlagának gyöke (Root-Mean-Square Error of Approximation, RMSEA, Steiger, 1990) $)^{5}$. A CFI azt méri fel, hogy egy feltételezett hipotetikus modell milyen mértékben reprodukálja a valós adatokon nyugvó kovarianciamátrixot egy független modellhez képest. A TLI a CFI-hez hasonló módon méri az illeszkedést, annyi különbséggel, hogy ez a mutató a modellben használt szabadságfokot is figyelembe veszi, így kiküszöböli a vizsgálati minta méretének befolyásoló szerepét. A CFI és TLI mutatók értéke 0 és 1 közötti tartományba eshet, ahol az 1-hez közeli érték jelzi a szoros illeszkedést. Kezdetben a mutatók elfogadhatósági kritériumának 0,90-et adtak meg, de az utóbbi időkben inkább a 0,95-ot tekintik az elfogadhatóság alsó határának (Hu \& Bentler, 1999). A Steiger-féle RMSEA mutatót a modell populációs kovariancia mátrixhoz viszonyított illeszkedésének becsléséhez használjuk. Az RMSEA az elemszámtól függetlenül hasonlítja össze, hogy a valós és az optimális paraméterekkel rendelkező hipotetikus modell

5 Érdemes megjegyezni, hogy a fenti illeszkedési mutatóknak nincs széles körben elterjedt magyar elnevezése, a kutatók leginkább az angol rövidítéseket alkalmazzák. A továbbiakban mi is a rövidítésekkel hivatkozunk a mutatókra. 
kovarianciamátrixa milyen mértékben illeszkedik. Az RMSEA a modell takarékosságának megbízható jelzője, a komplex modellek hibás specifikálásának hatékony mutatója. Az RMSEA értéke is 0 és 1 közé eshet, itt azonban a kisebb, 0-hoz közel eső érték jelzi a jobb illeszkedést. Browne és Cudeck (1993) szerint az RMSEA értékei 0,05-ig szoros illeszkedést jeleznek; 0,08-os értékig pedig megfelelő illeszkedést, elfogadható populáción belüli becslési hibákkal.

A csoportok (nők és férfiak, normatív és klinikai minta) közötti összehasonlításokat kétmintás t-próba segítségvel vetettük össze. Ha a Levene-teszt a szórások szignifikáns eltérését jelezte, akkor Welch-féle d-próba eredményeit vettük figyelembe. A változók közötti együttjárásokat Pearson-féle korrelációs együtthatókkal jellemeztük.

A leíró statisztikai elemzéseket, a csoportok közötti összehasonlításokat (kétmintás t-próba, Welch-féle $d$-próba), és a változók közötti kapcsolatokat (Pearson-féle korrelációs elemzés) az SPSS 22 (IBM Corp. 2013), a faktorelemzéseket az MPLUS 8.2 (Muthén \& Muthén, 1998-2017) és az ingyenesen használható FACTOR (Lorenzo \& Ferrando, 2006, 2013) elnevezésú programokkal, a valószínúségi tesztelmélet alapján történő itemparaméterek becslését (nehézség és diszkrimináció) és az eltéró tételmúködést (DIF) pedig az IRTPRO szoftver (Cai és mtsai, 2011) segítségével készítettük el.

\section{Eredmények}

\subsection{A Mágikus Fogalomképzés Skála faktorszerkezete}

\subsubsection{Feltáró faktorelemzés}

Elsőként parallel-elemzés (Horn, 1965) segítségével arra kerestük a választ, hogy a Mágikus Fogalomképzés Skála 30 tétele hány dimenzió köré csoportosítható, illetve tekinthető-e egydimenziósnak a különböző vizsgálati mintákon (normatív és klinika). A normatív mintán végzett szimulációs módszer 3 szignifikáns dimenzió meglétét jelezte, míg a kis elemszámú klinikai mintán 1 vagy 2 faktort valószínúsített. ${ }^{6}$

\footnotetext{
${ }^{6}$ Fontos megjegyezni, hogy a klinikai mintán képzett szimuláció véletlenszerúen képzett második faktora esetében a sajátérték varianciájának átlaga nem haladta meg a tényleges adatokon nyert sajátértéket $(6,7$ vs. 7,1), ellenben a 95\%-os konfidencia intervallum felső határértéke $(7,2)$ nagyobb volt, mint a valós adatokon nyert sajátérték. Így az elemzés alapján 1 vagy 2 faktor valószínúsíthető.
} 
A következő lépésben feltáró faktorelemzést végeztünk a véletlenszerúen kettéválasztott normatív vizsgálati minta egyik felén. A faktorelemzésnél a tetrakorikus korrelációt alkalmaztuk a legkisebb négyzetek súlyozott módszerével, ${ }^{7}$ mivel a változóink dichotómak, és az elózetes vizsgálatok eredményei alapján azt kaptuk, hogy a normalitás több esetben is sérült. ${ }^{8}$ Nyolc egynél nagyobb sajátértékú komponenst azonosítottunk, amelyből az első az összvariancia 27,4\%-át magyarázta, a második 7,6\%-ot, a harmadik pedig 6,6\%-ot. A további komponensek magyarázóereje 5\% alatt volt. Általánosan elfogadott, hogy ha a faktorelemzés során kapott első komponens magyarázó ereje eléri a $20 \%$-ot, a másodiké pedig nem éri el az első komponens magyarázó erejének harmadrészét, akkor egydimenziós struktúrát valószínúsíthetünk (Drasgow és Parsons, 1983; Morizot és mtsai, 2009). A klinikai minta elemzésekor 9 egynél nagyobb sajátértékú komponenst kaptunk, és az első és második komponensek magyarázó erejének aránya szintén meghaladta a hármat: $22,2 \%$ vs. $6,7 \%$.

A fenti, egymásnak ellentmondó eredmények (a feltáró faktorelemzés egydimenziós szerkezetre utaló jellemzői és a parallel-elemzés több dimenziót valószínúsítő eredménye) feloldására megvizsgáltuk a normatív mintán kapott 3 faktoros szerkezetet, illetve a klinikai minta 2 faktoros szerkezetét, amit a parallel-elemzés valószínúsített.

A normatív mintán a 3 faktoros megoldás az összvariancia közel 42\%-át magyarázza. A fentiekben már jeleztük, hogy az első faktor magyarázóereje kiemelkedik a másik kettőhöz viszonyítva (2. táblázat). Láthatjuk, hogy a faktorsúlyok változatosak és több olyan tétel is akad, amelyek egyetlen faktorral sem mutatnak számottevő korrelációt $(<0,40)$, illetve vannak olyan tételek, amelyek egyidejúleg több faktorral is korrelálnak.

\footnotetext{
7 Weighted Least Squares Mean and Variance adjusted: WLSMV.

8 Mivel a faktorelemzés eredményét jelentősen torzíthatja a változók normalitásának sérülése, így előzetesen a változók eloszlását és normalitását (egy-és többváltozós) vizsgáltuk meg. Mivel a kérdőív tételeinek értékelése dichotóm válaszformátumú skálán történik, így ezek a változók nem tekinthetók folytonos intervallum skáláknak, így nem meglepő, hogy a normalitást tesztelő hagyományos próbák (pl. Kolmogorov-Smirnov-teszt, Shapiro-Wilk-teszt, Mardia-féle többváltozós ferdeség és csúcsosság mutató) kritériumainak általában nem felelnek meg. A fentieknek megfelelően inkább azt vizsgáljuk, hogy a változók normalitása milyen mértékben sérül. Bár nincs egyértelmúen meghatározott kritérium, a módszertani ajánlások szerint, a nagyobb elemszámú vizsgálati minták esetén $(n>300)$, leginkább a ferdeség abszolút értékben 2 alatti értéke, valamint a csúcsosság 7 alatti értéke elfogadható (Chou \& Bentler, 1995; Curran, West, \& Finch, 1996; Muthén \& Kaplan, 1985). A normatív mintában a ferdeségmutató 10 változó esetében haladta meg a 2 értéket, míg a klinikai minta esetében 5 . A csúcsosságmutatónál a normatív mintában 5, míg a klinikai mintában 1 változó esetében kaptunk 7-nél nagyobb értéket.
} 
A legnagyobb magyarázóerővel rendelkező első faktorba fóként a paranormális jelenségekkel és a téveszmékkel kapcsolatos hiedelmek kerültek, amelyek az énhatárok gyengeségére és a fokozott jelentéstulajdonításra utalnak: pl. Néha észreveszek olyan hangokat is a felvételeken, amik máskor nincsenek ott.

A második dimenzióba a mágikus oksággal és a spiritualitással kapcsolatos tételek szerveződtek: pl. Tünődtem már azon, hogy vajon a holtak lelke befolyásolja-e az élóket.

A leggyengébb magyarázóeróvel rendelkező harmadik dimenziót alkotó tételek közös jellemzője a mágikus hiedelmek elutasítása, amelyet - egyetlen kivételtől eltekintve - a skála fordított megfogalmazású tételei alkotnak: pl. Soha nem éreztem azt, hogy bizonyos gondolataim valójában valaki más gondolatai lennének.

Fontos megjegyezni, hogy a skála 7 fordított tételéből csak 6 tartozik ide, a 23. tétel (Amikor idegeneknek mutatnak be, néha azon tünödöm, vajon találkoztam-e már velük korábban) az első faktorhoz sorolódik. A fenti fordított tétel eltérő múködésének ellenőrzéséhez ismételten megvizsgáltuk az eredeti angol megfogalmazást (When introduced to strangers I rarely wonder if they have known me before), és észrevettük, hogy fordítási pontatlanság következtében fordult meg a tétel iránya. Az eredeti angol tétel „rare” szava azt fejezi ki, hogy "szinte sohasem” vagy „csak ritkán” túnődöm azon, hogy az idegenek ismernek-e engem korábbról, míg a magyar fordítás „néha azon túnődöm" kifejezése sokkal megengedőbb, azt jelzi, hogy elő szokott ilyen fordulni. Ez a szemantikai eltérés lehet a magyarázat arra, hogy a tétel iránya megfordult, és így a spirituális dimenzióval mutat kapcsolatot.

A nagy elemszámú normatív mintán a gyenge faktorsúlyú $(<0,40)$ és a jelentős mértékú $(\geq 0,30)$ kereszttöltéssel rendelkező tételek elhagyásával két olyan faktort alakítottunk ki, amelyek pszichometriai értelemben a mágikus fogalomképzés tisztább komponensei. ${ }^{9}$ A kiválasztott tételeket szürke háttérrel emeltük ki a 2. táblázatban.

A klinikai mintán végzett kétfaktoros feltáró elemzés összességében az egydimenziós szerkezetet erősítette meg, mivel a második faktorba került az összes fordított tétel (a 23. tétel kivételével), amit módszerból fakadó melléktermékként értelmeztünk (ld. részletesen a következő fejezetben).

\footnotetext{
9 A kiválasztott tételek faktorsúlyai 0,4-nél nagyobbak, és más faktorokkal nem mutatnak jelentős $(\geq 0,30)$ kereszttöltést.
} 
2. táblázat. A Mágikus Fogalomképzés Skála tételein végzett feltáró faktorelemzés eredménye (normatív és klinikai minta, R: fordított tétel)

\begin{tabular}{|c|c|c|c|c|c|}
\hline \multirow[b]{2}{*}{ A Mágikus Fogalomképzés Skála tételei } & \multicolumn{3}{|c|}{$\begin{array}{l}\text { Normatív } \\
\text { minta }\end{array}$} & \multicolumn{2}{|c|}{$\begin{array}{l}\text { Klinikai } \\
\text { minta }\end{array}$} \\
\hline & I. & II. & III. & I. & II. \\
\hline $\begin{array}{l}\text { Néhány emberről már azáltal tudomást szerzek, } \\
\text { hogy rám gondolnak. }\end{array}$ & 0,26 & 0,34 & $-0,12$ & 0,48 & $-0,07$ \\
\hline $\begin{array}{l}\text { Volt már olyan érzésem, hogy talán nem is vagyok } \\
\text { emberi lény. }\end{array}$ & 0,58 & 0,30 & 0,10 & 0,31 & $-0,03$ \\
\hline Előfordult, hogy féltem rálépni a járda repedéseire. & 0,30 & 0,17 & 0,03 & 0,34 & $-0,16$ \\
\hline $\begin{array}{l}\text { Szerintem képes lennék mások elméjében olvasni, } \\
\text { ha akarnám. }\end{array}$ & 0,37 & 0,35 & $-0,11$ & 0,40 & $-0,07$ \\
\hline $\begin{array}{l}\text { A horoszkópok túl gyakran igazak ahhoz, hogy } \\
\text { véletlenek legyenek. }\end{array}$ & 0,00 & 0,46 & $-0,25$ & 0,45 & 0,09 \\
\hline $\begin{array}{l}\text { Mikor hazaérek, néha úgy túnik, a dolgok más } \\
\text { helyre kerültek, annak ellenére, hogy senki sem } \\
\text { járt ott. }\end{array}$ & 0,63 & 0,04 & $-0,02$ & 0,52 & 0,04 \\
\hline $\begin{array}{l}\text { Bizonyos számok, mint például a } 13 \text { és } 7 \text { semmilyen } \\
\text { különleges eróvel nem rendelkeznek. (R) }\end{array}$ & $-0,09$ & $-0,11$ & 0,47 & $-0,17$ & 0,39 \\
\hline $\begin{array}{l}\text { Néha volt már olyan furcsa érzésem, hogy a rádiós } \\
\text { vagy tévés músorvezető tudta, hogy hallgatom őt. }\end{array}$ & 0,80 & $-0,13$ & 0,06 & 0,42 & $-0,01$ \\
\hline $\begin{array}{l}\text { Aggódtam már amiatt, hogy más bolygókon élő } \\
\text { emberek befolyásolhatják azt, ami a Földön történik. }\end{array}$ & 0,43 & 0,30 & $-0,03$ & 0,43 & $-0,12$ \\
\hline $\begin{array}{l}\text { A kormány megtagadja tőlünk az igazságot a repülő } \\
\text { csészealjakról. }\end{array}$ & 0,14 & 0,27 & $-0,14$ & 0,39 & $-0,15$ \\
\hline $\begin{array}{l}\text { Éreztem már azt, hogy a tárgyak elrendezése, } \\
\text { például egy kirakat berendezése üzenetet közvetít } \\
\text { számomra. }\end{array}$ & 0,53 & 0,26 & $-0,01$ & 0,58 & 0,03 \\
\hline $\begin{array}{l}\text { Soha nem kételkedtem abban, hogy az álmaim } \\
\text { a saját elmém szüleményei. (R) }\end{array}$ & $-0,16$ & 0,11 & 0,29 & 0,01 & 0,55 \\
\hline A szerencsehozó talizmánok nem múködnek. (R) & 0,06 & $-0,06$ & 0,34 & 0,10 & 0,32 \\
\hline $\begin{array}{l}\text { Néha észreveszek olyan hangokat is a felvételeken, } \\
\text { amik máskor nincsenek ott. }\end{array}$ & 0,86 & $-0,05$ & $-0,01$ & 0,47 & $-0,11$ \\
\hline $\begin{array}{l}\text { Időnként úgy túnik, az idegen emberek } \\
\text { kézmozdulatai befolyásolnak engem. }\end{array}$ & 0,67 & 0,09 & 0,06 & 0,47 & $-0,16$ \\
\hline $\begin{array}{l}\text { Szinte soha nem álmodom meg a dolgokat } \\
\text { a megtörténtük elótt. (R) }\end{array}$ & 0,07 & $-0,13$ & 0,49 & 0,02 & 0,18 \\
\hline
\end{tabular}




\section{2. táblázat (folytatás)}

\begin{tabular}{|c|c|c|c|c|c|}
\hline \multirow[b]{2}{*}{ A Mágikus Fogalomképzés Skála tételei } & \multicolumn{3}{|c|}{$\begin{array}{c}\text { Normatív } \\
\text { minta }\end{array}$} & \multicolumn{2}{|c|}{$\begin{array}{l}\text { Klinikai } \\
\text { minta }\end{array}$} \\
\hline & I. & II. & III. & I. & II. \\
\hline $\begin{array}{l}\text { Előfordult már, hogy egy pillanatra úgy éreztem, } \\
\text { hogy valaki helyét egy hasonmása vette át. }\end{array}$ & 0,86 & $-0,06$ & $-0,14$ & 0,48 & $-0,22$ \\
\hline $\begin{array}{l}\text { Lehetetlen másokat bántani azáltal, hogy rossz } \\
\text { dolgokat gondolunk róluk. (R) }\end{array}$ & $-0,14$ & $-0,03$ & 0,43 & 0,02 & 0,34 \\
\hline $\begin{array}{l}\text { Előfordult már, hogy éreztem a gonosz jelenlétét } \\
\text { magam körül, annak ellenére, hogy nem láttam. }\end{array}$ & 0,31 & 0,47 & $-0,04$ & 0,61 & $-0,11$ \\
\hline $\begin{array}{l}\text { Néha azt érzem, hogy energiát nyerek vagy vesztek } \\
\text { azáltal, hogy bizonyos emberek rám néznek vagy } \\
\text { megérintenek. }\end{array}$ & 0,13 & 0,65 & 0,05 & 0,52 & 0,26 \\
\hline $\begin{array}{l}\text { Volt már olyan futó gondolatom, hogy idegen } \\
\text { emberek szerelmesek belém. }\end{array}$ & 0,25 & 0,21 & 0,11 & 0,41 & $-0,06$ \\
\hline $\begin{array}{l}\text { Soha nem éreztem azt, hogy bizonyos gondolataim } \\
\text { valójában valaki más gondolatai lennének. (R) }\end{array}$ & $-0,07$ & 0,11 & 0,54 & $-0,11$ & 0,35 \\
\hline $\begin{array}{l}\text { Amikor idegeneknek mutatnak be, néha azon } \\
\text { túnődöm, vajon találkoztam-e már velük korábban. } \\
\text { (R) }\end{array}$ & $-0,01$ & 0,49 & 0,00 & 0,45 & 0,12 \\
\hline $\begin{array}{l}\text { Ha a reinkarnáció valóban létezne, az sok különös } \\
\text { élményemet megmagyarázná. }\end{array}$ & $-0,10$ & 0,67 & $-0,21$ & 0,53 & 0,15 \\
\hline $\begin{array}{l}\text { Az emberek gyakran olyan furcsán viselkednek, } \\
\text { hogy eltúnődöm vajon nem egy kísérlet } \\
\text { résztvevői-e. }\end{array}$ & 0,44 & 0,22 & 0,00 & 0,58 & $-0,02$ \\
\hline $\begin{array}{l}\text { Néha a negatív hatások elhárítása érdekében } \\
\text { bizonyos rituálékat hajtok végre. }\end{array}$ & 0,13 & 0,50 & 0,11 & 0,50 & 0,13 \\
\hline $\begin{array}{l}\text { Éreztem már azt, hogy megtörténtté tehetek valamit } \\
\text { pusztán azáltal, hogy túl sokat gondolok rá. }\end{array}$ & $-0,09$ & 0,69 & 0,01 & 0,53 & 0,28 \\
\hline $\begin{array}{l}\text { Túnődtem már azon, hogy vajon a holtak lelke } \\
\text { befolyásolja-e az élőket. }\end{array}$ & $-0,04$ & 0,67 & 0,05 & 0,47 & 0,04 \\
\hline $\begin{array}{l}\text { Néha megtörtént, hogy azt éreztem az egyetemi } \\
\text { elóadáson a professzor szavai külön nekem szólnak. }\end{array}$ & 0,19 & 0,35 & 0,09 & 0,54 & 0,02 \\
\hline $\begin{array}{l}\text { Előfordult néha, hogy azt éreztem, idegenek } \\
\text { olvasnak a gondolataimban. }\end{array}$ & 0,34 & 0,42 & 0,08 & 0,68 & $-0,08$ \\
\hline Magyarázott variancia (\%) & 27,4 & 7,6 & 6,6 & 21,5 & 6,6 \\
\hline Cronbach- $\alpha$ & 0,75 & 0,72 & 0,51 & 0,86 & 0,51 \\
\hline
\end{tabular}




\subsubsection{A negatív tételek önálló faktorba rendeződésének problémája}

A feltáró faktorelemzés során kapott eredmények mindkét mintában (normatív és klinikai) megerősítik a fordított tételek elkülönülését, önálló dimenzióba szerveződését. A pozitív és negatív tételek elkülönülése a faktorelemzés során viszonylag gyakori jelenség. A szakirodalomban a skála mérési tartományának megfelelően nevezik el a tételeket pozitív és negatív irányúnak. Pozitívnak azokat a tételeket nevezik, amelyek az eredeti skála irányával egybeesnek, míg a negatív pontozásúnak nevezett tételek ellentétes irányúak. A negatív tételeket általában azért építik be a kérdőívekbe, hogy a válaszadási mintázat torzító hatását kivédjék. Ilyen torzító válaszadási mintázat lehet, ha a kitöltő az első kérdések megválaszolása után felismeri a tételek tartalmát, és a következő tételekre való válaszadás során már a tétel alapos végigolvasása és mérlegelése nélkül, automatikusan megjelöli a korábbi tételekre adott véleményét tükröző választ. Ezzel szemben, a negatív tételek elvileg egy olyan kognitív „sebességkorlátozást” jelenthetnek, amely csökkenti az automatikus válaszadás kialakulását és arra kényszeríti a kitöltőt, hogy gondosabban mérlegelje a tételek tartalmát. Sajnos a kutatási eredmények azonban azt tükrözik, hogy a fordított tételek gyakran egy mesterséges válaszadási faktort hoznak létre, ami teljesen eltúnik, ha a negatív tételeket pozitív irányúra fogalmazzák át (Harvey, Billings, \& Nilan, 1985; Idaszak \& Drasgow, 1987). A pozitív és negatív tételek különválásának hátterében leggyakrabban az áll, hogy egy kérdőívre kialakult válaszbeállítódást követően sok kitöltő nem képes a negatív tételek felismerésére. Schmitt és Stults (1986) kimutatták, hogy a negatív tételek faktorba szerveződése már akkor megjelenhet, ha a válaszadóknak mintegy 10\%-a nem ismeri fel azt, hogy néhány tétel fordított pontozású, vagyis negatívan megfogalmazott. Woods (2006) szimulációs vizsgálatok segítségével azt találta, hogy negatív irányú tételeket is tartalmazó egydimenziós mérőeszköz esetében már az is elég a megerősítő faktorelemzések alacsony illeszkedési mutatóihoz (ezáltal az egydimenziós szerkezet elvetéséhez), ha a vizsgálati minta $10 \%$-a ad pontatlan válaszokat a fordított tételekre.

Fontos kiemelni, hogy a Mágikus Fogalomképzés Skála 30 tételéből mindössze 7 negatív tétel van, amelyeket minden bizonnyal a szerzők a válaszbeállítódás kivédése miatt fogalmaztak meg ellentétes irányúnak. Ezeket a tételeket a kérdőív közepén helyezték el. A pozitív és negatív tételek számának aránya tehát jelentősen eltér (23 vs. 7). Láthattuk, hogy a fordítási pontatlanság következtében pozitívra változtatott 23. tétel elkülönült a többi negatív tételtől, csakúgy, mint a fent említett kutatásokban (Harvey, Billings, \& Nilan, 1985; Idaszak \& Drasgow, 1987). A maradék 6 negatív tétel belső konzisztenciája alacsony (mindkét minta esetében a Cronbach- $\alpha$ mutató értéke 0,51). A 6 negatív tételből álló skála, más skálákkal történő 
összevetés során, egyetlen esetben sem adott olyan mértékú együttjárást, ami a dimenzió érvényességét alátámasztotta volna (a más validáló módszerekkel történő összevetés során a korrelációs együtthatók értékei abszolút értékben 0,15 alatt maradtak).

A fenti megfontolások alapján a kapott dimenziót a módszerből fakadó mellékterméknek tekintjük, így ezt a továbbiakban nem elemezzük.

\subsubsection{Megerősitő faktorelemzés}

A normatív mintán kapott 1 és 2 faktoros megoldások, illetve a nemzetközi szakirodalmi eredmények (Çam és mtsai, 2014; Cicero és mtsai, 2019; Fonseca-Pedrero és mtsai, 2009; Garzitto és mtsai, 2016; Horan és mtsai, 2004; Johnston, 1991; Winterstein és mtsai, 2011ab) azt sugallják, hogy az egydimenziós szerkezet mellett a bifaktoros megoldást is érdemes megvizsgálni. A bifaktoros elrendeződés jellemzője, hogy az egyes tételek egy általános dimenzióba (Fg) és specifikus faktorokba is szerveződnek egyidejúleg (1. ábra). Ez a tesztfelhasználási gyakorlatban azt jelenti, hogy a fóskála mellett az alskálák is hasznos támpontot nyújthatnak az értékelés során. Az ilyen típusú elrendeződésre számos példát láthatunk: Beck Depresszió Kérdőív (BDI) (Brouwer, Meijer, \& Zevalink, 2013; García-Batista, Guerra-Peña, Cano-Vindel, Herrera-Martínez, \& Medrano, 2018), Derogatis-féle Tünetlista (SCL-90R) (Urbán és mtsai, 2014), Wechsler Intelligenciatesztek (WISCIV, WAIS-IV, WPPSI-IV) (Gignac \& Watkins, 2013; Watkins, 2010).

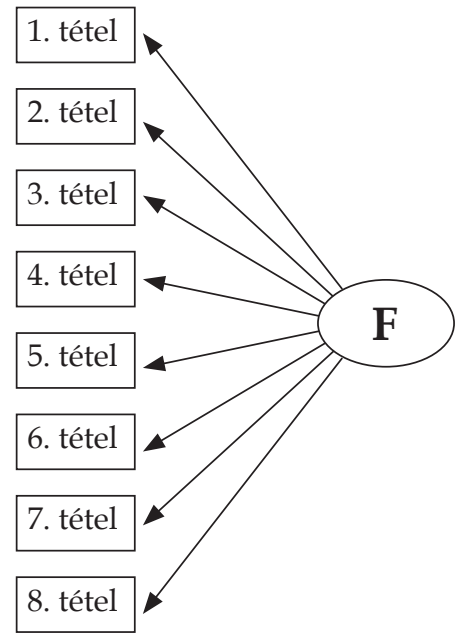

a. Egyfaktoros modell modell

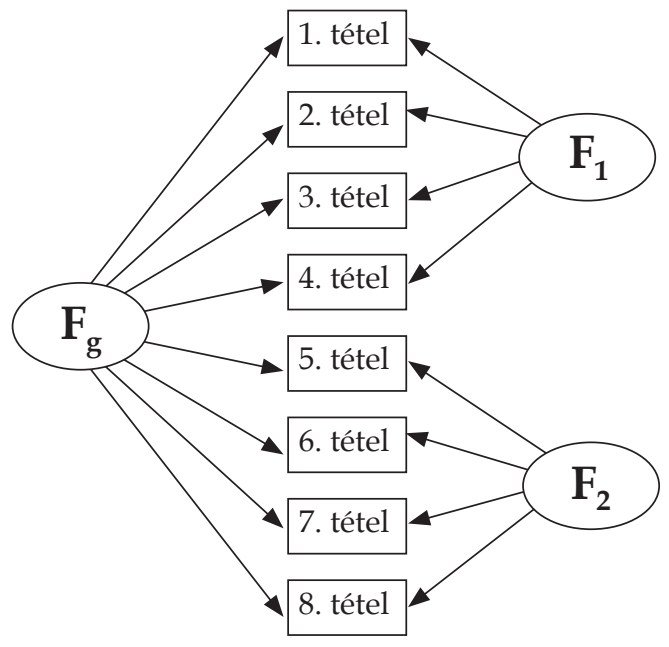

b. Bifaktoros modell

1. ábra. A hipotetikus faktorszerkezetek szemléltetése 
A véletlenszerúen kettéválasztott normatív minta második felén végzett megerősítő faktorelemzés illeszkedési mutatói az elvártaktól alacsonyabbak, így a Mágikus Fogalomképzés Skála a normatív mintán nem tekinthetó egydimenziósnak (3. táblázat). Ha a fordított tételeket elhagyjuk, akkor az így kapott 24 tételból álló változat illeszkedési mutatói már elfogadhatóak, vagyis ez a változat már tekinthetó egydimenziósnak. A kétfaktoros szerkezetnek leginkább megfelelő tételek kiválasztásával nyert 15 tételes skála érthetó módon alacsonyabb illeszkedési mutatókat eredményezett, mint a 24 tételes változat. Ennek legfóbb oka, hogy a „tiszta” faktorszerkezet érdekében több olyan tételt is elhagytunk, amely mindkét faktorral jelentős mértékú korrelációt mutatott. A 15 tételes változat bifaktoros elrendezésben viszont kiemelkedően magas illeszkedési mutatókat adott, jelezve, hogy ez a modell illeszthetó leginkább az adatainkra.

A fenti modellek klinikai mintán történő elemzésekor az egydimenziós szerkezetek minden változatban elfogadható illeszkedéseket adtak, ami a parallel-elemzés és a feltáró elemzés eredményeivel jól összeegyeztethető. Az illeszkedési mutatók értékelése alapján a 15 tételes változat a klinikai mintán inkább egydimenziósnak tekinthetó, mivel a bifaktoros megoldás illeszkedési mutatói valamennyire gyengébbek az egydimenziósnál.

3. táblázat. A Mágikus Fogalomképzés Skála különböző változatainak illeszkedési mutatói

\begin{tabular}{|c|c|c|c|c|c|}
\hline Modell & $\chi^{2}$ & df & RMSEA & CFI & TLI \\
\hline Normatíu minta $(n=895)$ & 918,94 & 405 & 0,038 & 0,881 & 0,872 \\
\hline egydimenziós (30 tétel) & 565,77 & 275 & 0,034 & 0,925 & 0,918 \\
\hline egydimenziós (24 tétel) & 295,60 & 90 & 0,053 & 0,895 & 0,877 \\
\hline egydimenziós (15 tétel) & 87,15 & 75 & 0,014 & 0,993 & 0,990 \\
\hline bifaktoros (15 tétel) & & & & \\
\hline Klinikai minta ( $n=319)$ & 528,19 & 405 & 0,041 & 0,916 & 0,910 \\
\hline egydimenziós (30 tétel) & 310,08 & 275 & 0,036 & 0,957 & 0,953 \\
\hline egydimenziós (24 tétel) & 113,81 & 90 & 0,032 & 0,970 & 0,965 \\
\hline egydimenziós (15 tétel) & 94,61 & 75 & 0,039 & 0,959 & 0,943 \\
\hline bifaktoros (15 tétel)
\end{tabular}




\subsection{A Mágikus Fogalomképzés Skála rövidített változatának pszichometriai jellemzői}

Mivel az elemzéseink egyik fontos célkitúzése, hogy olyan rövidített változatot alakítsunk ki, amely úgy normatív, mint klinikai mintákon jól használható, a következőkben megvizsgáljuk a 15 tételes változat részletes pszichometriai jellemzőit a normatív és a klinikai mintán egyaránt. A teljes normatív mintán kapott egydimenziós faktorszerkezet faktorsúlyai $(\lambda)$ elfogadható mértékúek, csupán két olyan tétel van (23. és 24.), amelyek faktorsúlyai 0,50 alattiak. A klinikai mintán a faktorsúlyok összességében valamivel magasabbak, és látható, hogy néhány tétel eltérő faktorsúllyal bír a két mintán. A legnagyobb eltérés a 24. tétel esetében látható (Ha a reinkarnáció valóban létezne, az sok különös élményemet megmagyarázná.). A 15 tételes skála belső konzisztenciáját becslő Cronbach- $\alpha$ mutatók mindkét mintán elfogadhatóak: 0,75 és 0,82 .

A normatív mintán végzett bifaktoros elemzés általános faktorát (Fg) alkotó tételek megközelítóen az egydimenziós elemzésnél kapott faktorsúlyokhoz hasonlítanak. A speciális faktorok (F1: Paranormális hiedelmek és F2: Mágikus okság és spiritualitás) esetében már sokkal változatosabbak a faktorsúlyok. Az első faktor 8 tételéből a fele nem éri el a 0,3-es faktorsúlyt, a másodikban pedig 3 ilyen tétel található. A fó- és az aldimenziók reliabilitásának vizsgálatára alternatív megbízhatósági mutatót számoltunk. A McDonald (1999) által bevezetett ómega ( $\omega)$ együttható azt fejezi ki, hogy az összpontszám varianciájának mekkora hányada magyarázható a közös faktorral vagy faktorokkal. Ezt a mutatót az aldimenziók megbízhatóságának jellemzésére is alkalmazzák, ahol az aldimenziók pontszámának varianciáját vetik össze a közös faktorok által leírt varianciával. A hierarchikus ómega együttható $\left(\omega^{\mathrm{h}}\right)$ pedig azt fejezi ki, hogy az összpontszám varianciájának mekkora hányada magyarázható csak az általános faktorral (Fg), illetve az aldimenzió hierarchikus ómega mutatójának kiszámításakor az aldimenzió varianciáját csak a specifikus faktor varianciájával vetjük össze, úgy, hogy az általános faktor hatását kontrolláljuk. Mivel az ómega együttható a Cronbach- $\alpha$ mutatóhoz hasonló, így gyakran a 0,70-es elfogadhatósági kritériumot alkalmazzák az ómega együttható esetében is. Reise (2012) szerint az ómega együtthatónak legalább a 0,50-es szintet mindenképpen el kell érnie. Jelen mintánkban a Cronbach- $\alpha$ mutatók és az ómega együtthatók értékei összességében elfogadhatóak, bár látható, hogy a Paranormális hiedelmek faktor (F1) esetében a Conbach- $\alpha$ nem éri el a 0,70-et. A hierarchikus ómega együtthatók esetében csak az általános faktor $(\mathrm{Fg})$ rendelke- 
zik jó megbízhatósági mutatóval, a specifikus faktorok hierarchikus ómega együtthatói alacsonyak, ami a skálák alacsony megbízhatóságát jelzi.

A 4. táblázatban a faktorok (általános és speciális) által megmagyarázott közös varianciát (Explained Common Variance: ECV), továbbá az egyes tételekre adott válaszok és általános faktor közös varianciahányadát (Individual Explained Common Variance: IECV) is szemléltetjük. Mindezek mellett kiszámoltuk a tisztán egydimenziós modell által megmagyarázott varianciahányadot (Percent of Uncontaminated Correlations, PUC) is, amely szintén az általános faktor által megmagyarázott varianciahányadot ragadja meg, de más módon, mint az ECV. Bár a fenti mutatóknak nincs széles körben elfogadott határértéke Rodriguez és munkatársai (2016) úgy tartják, hogy a 0,70-nél magasabb ECV és PUC mutatók az egydimenziós modell érvényességét támasztják alá. Reise és munkatársai (2013) érvelése szerint, ha a PUC mutató kisebb, mint 0,80 , az általános faktor által magyarázott ECV mutató nagyobb, mint 0,60, továbbá az általános faktor hierarchikus ómega együtthatója nagyobb, mint 0,70, akkor ezek az eredmények valamilyen mértékú multidimenzionalitás jelenlétét támogatják, de ez még nem feltétlenül zárja ki azt, hogy a méróeszközt elsődlegesen egydimenziósként értelmezzük. Az egyes tételek és az általános faktor közös varianciahányada (IECV) esetében általában a 0,80 vagy 0,85-nál nagyobb mutatók esetében tartják úgy, hogy a tétel egyértelmúen az általános látens dimenziót méri (Stucky és Edelen, 2015).

A 15 tételes Mágikus Fogalomképzés Skála bifaktoros modelljénél a PUC 0,53, az ECV 0,77, az általános faktor hierarchikus ómega együtthatója pedig 0,82. A 15 tételből 9 esetében (60\%) 0,80 vagy annál magasabb IECV mutatókat látunk.

A valószínúségi tesztelmélet (Item Response Theory, IRT) megközelítést alkalmazva a normatív és a klinikai mintán egyaránt kiszámítottuk az egyes tételek nehézség $(b)$ és diszkriminációs $(a)$ mutatóit. A megközelítés lehetővé teszi a tételre adott válaszok (igen-nem) és a válasz hátterében álló látens vonás (jelen esetben: mágikus fogalomképzés) egyidejú vizsgálatát. A nehézség a tétel helyét, ún. lokációját mutatja meg a vizsgált látens vonás kontinuumán, ahol annak valószínúsége, hogy a személy „igen” választ ad, $50 \%$. Minél magasabb értéket vesz fel a nehézség mutató, annál „nehezebbnek" számít a tétel, és annál magasabb látens vonás szükséges az „igen” válaszhoz. A diszkriminációs mutató a tétel lokációs pontjánál lévő meredekséget határozza meg, és azt fejezi ki, hogy a tétel mennyire áll szoros kapcsolatban a látens vonással. Minél magasabb a mutató értéke, annál pontosabban ragadja meg a tétel az adott látens vonást, és annál jobban differenciál a személyek között (2. ábra). Szélsőséges esetben, ha a görbe meredeksége a 0 fokhoz közelít, akkor az azt jelenti, hogy a tételre adott válaszokat a látens vonások mértéke nem befolyásolja. 


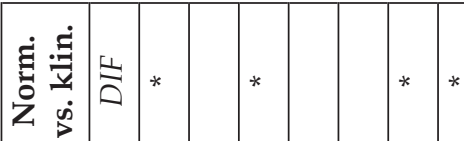

$$
\begin{aligned}
& \text { 葛 }
\end{aligned}
$$

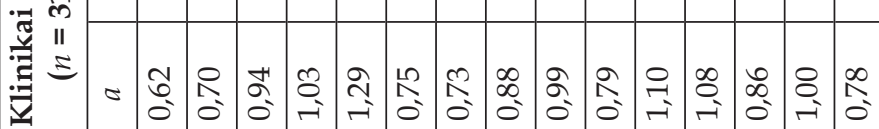

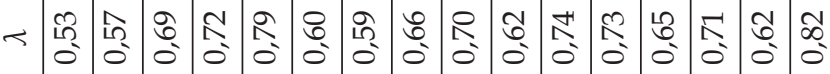

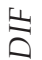$$
\frac{\pi}{+}
$$

岕

तi

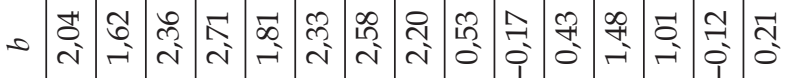

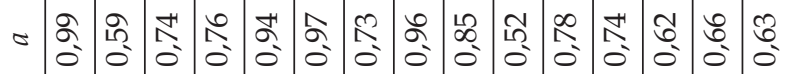

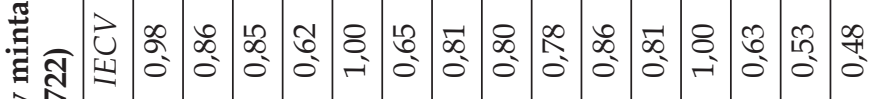

$$
\begin{aligned}
& \text { 究 }
\end{aligned}
$$

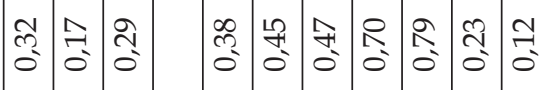

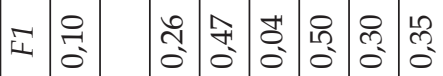

$$
\begin{aligned}
& \text { 芯 }
\end{aligned}
$$

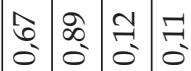

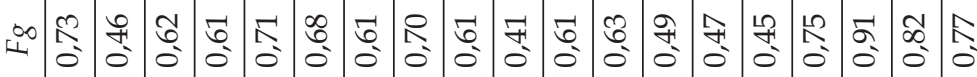

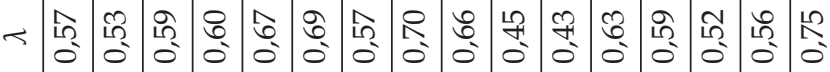

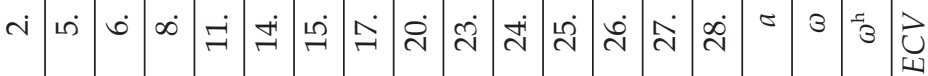

在

तิ 
Baker (1985) klasszifikációja alapján a diszkriminációs mutatót az alábbiak szerint értelmezhetjük: $a<0,20$ nagyon alacsony diszkrimináció; 0,21< $a<0,40$ alacsony diszkrimináció; 0,41 $<a<0,80$ mérsékelt diszkrimináció; $0,81<a<1,00$ magas diszkrimináció; $a \geq 1,00$ nagyon magas diszkrimináció.

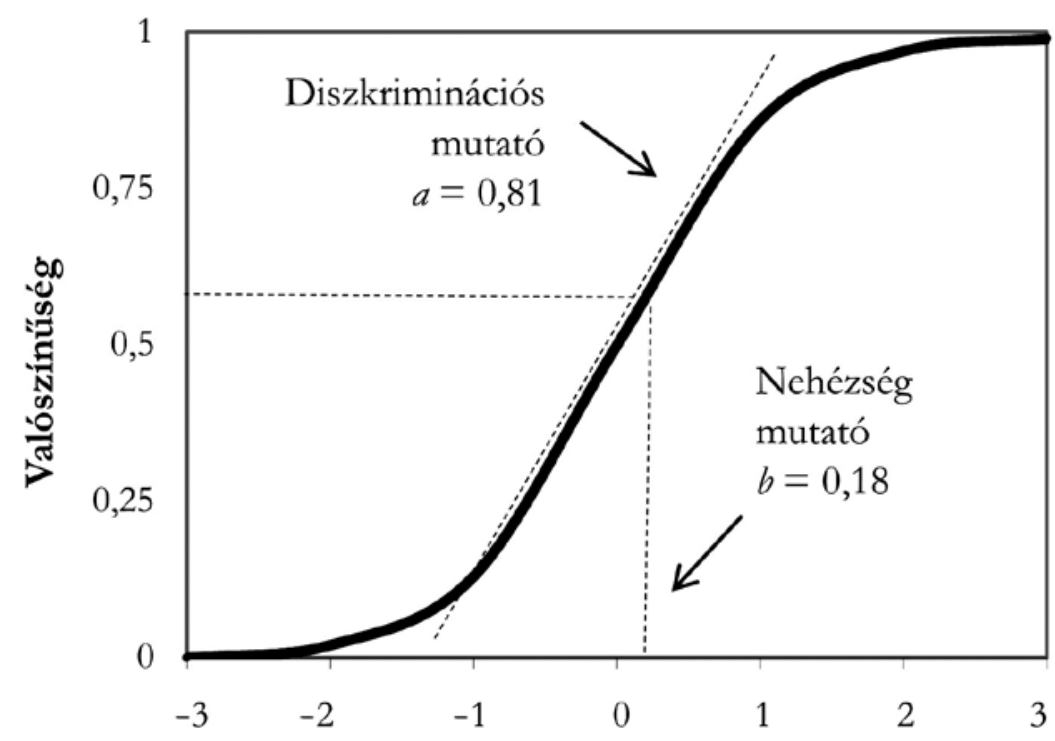

2. ábra. A tételjellemző görbe értelmezése

A normatív mintán kapott nehézségi mutatók (b) átlaga 1,40 (SD =1,00), ami azt jelzi, hogy a tételekre túlnyomórészt a magas látens vonással (az átlagtól 1,4 szórás távolságra) jellemezhető személyektől várható igen válasz (4. táblázat). Mindez azt mutatja, hogy a normatív mintába tartozó személyek többsége ezekre a kérdésekre nemmel válaszol. Mindössze négy olyan tétel (23., 27., 28., 24) van, ami az átlagos vonásövezetben (-0,5 és 0,5 között) mér, az igen válaszok aránya elérheti az 50\%-ot. A klinikai mintán a nehézségi mutatók $(b)$ átlaga kisebb mint $1(0,99 ; \mathrm{SD}=0,77)$, ami azt jelezi, hogy a mintába tartozó személyek alacsonyabb látens vonása is elegendő az „igen” válaszokhoz. Mindez a tételek klinikai alkalmazhatóságát szemlélteti, és arra utal, hogy normatív mintán az alacsony vagy átlagos látens vonásövezetben kevés igen választ fognak adni a kitöltók.

A diszkriminációs mutatók (a) átlaga a normatív mintán 0,76 (SD =0,15), és minden mutató a mérsékelt vagy a magas kategóriába sorolható. A legalacsonyabb diszkriminációs mutatóval a 23. tétel (Amikor idegeneknek mutatnak be, néha azon tünődöm, vajon találkoztam-e már velük korábban) ren- 
delkezik, ami azt jelzi, hogy a tételre adott válaszok és a látens vonás közötti kapcsolat gyengébb, mint a többi tétel esetében. Bár a tételek összességében jól differenciálnak, ennek ellenére a lokációs pontot $(b)$ is figyelembe véve, a tételek többsége inkább a magasabb látens vonással rendelkező személyek körében múködnek. A klinikai mintán a diszkriminációs mutató (a) átlaga magasabb $(0,90 ; \mathrm{SD}=0,18)$, ami azt jelzi, hogy a tételekre adott válaszok és a látens vonás között erősebb a kapcsolat, mint a normatív minta esetében. Ezek az eredmények összességében azt jelzik, hogy a mérőeszköz tételei elsődlegesen a mágikus fogalomképzés magas övezeteiben múködnek hatékonyan, ami a módszer klinikai alkalmazhatóságát támasztja alá.

A valószínúségi tesztelmélet kereteit felhasználva megvizsgáltuk, hogy a kiválasztásra került 15 tétel közül melyek azok, amelyek a nemi vagy klinikai csoportok összevetésekor eltérő jelentést hordoznak. Az alapvetó kérdés az, hogy az azonos mértékú látens vonással rendelkező, de különböző csoportba tartozó személyek (pl. férfi és nő, illetve normatív és klinikai csoport) egyes tételekre adott válaszainak megjelenési valószínúsége hasonló-e. Egy tételt akkor tekinthetünk összehasonlításra alkalmasnak, ha két különböző csoportba tartozó (pl. férfiak és nők), de a mért pszichológiai jellemző szempontjából (pl. mágikus fogalomképzés) azonos mértékkel jellemezhetó személy ugyanakkora valószínúséggel választja a tétel egy adott válaszlehetőségét. Ha ez a feltétel nem teljesül, akkor azt mondhatjuk, hogy a vizsgált tétel a csoportra nézve torzít, azaz eltérő jelentést hordoz a két csoport számára (Differential Item Functioning, DIF). A nemek összevetésekor a normatív mintán 5 olyan tételt azonosítottunk, amelyek eltéró jelentést hordoznak, torzítanak, míg a klinikai mintán nem találtuk ilyen tételt (az eltérő múködésú tételeket a 4. táblázat DIF oszlopában *-gal jelöltük). A normatív és a klinikai minta összevetésekor szintén 5 tételt találtunk, amelyek szignifikáns mértékú torzítással rendelkeznek.

\subsection{A Mágikus Fogalomképzés Skála érvényessége és leíró statisztikái}

Az alábbiakban a Mágikus Fogalomképzés Skála 15 tételes rövidített változatának, valamint az eredeti 30 tételból álló eredeti skálának a leíró statisztikáit, és a skálák validitását szemléltetjük.

A 15 tételes változat esetében normatív mintán a nők szignifikánsan magasabb pontszámot értek el a Mágikus okság és spiritualitás alskálán, valamint a Mágikus fogalomképzés skálán szemben a férfiakkal (5. táblázat). A Paranormális hiedelmek alskálán viszont a férfiak adtak szignifikánsan magasabb pontszámot. Az eredeti 30 tételes skálán szintén a nők értek el 
szignifikánsan magasabb eredményt, szemben a férfiakkal. A klinikai minta elemzése során csak a Mágikus okság és spiritualtitás skálán adtak magasabb pontszámot a nők, szemben a férfiakkal.

A normatív és a klinikai minta összevetésekor, a klinikai betegcsoport szignifikánsan magasabb átlagokat adott a Paranormális hiedelmek alskálán és a 15 tételből képzett Mágikus Fogalomképzés Skálán. A 30 tételből képzett Mágikus Fogalomképzés átlagai csak tendenciaszinten voltak magasabbak a betegcsoport esetében. Fontos kiemelnünk, hogy a Mágikus okság és spiritualitás alskálán azonban nem volt számottevő eltérés a normatív és a klinikai csoport átlagában.

5. táblázat. A Mágikus Fogalomképzés Skála leíró statisztikái:

normatív és klinikai minta, illetve nők és férfiak eredményeinek összehasonlító elemzése (t: a kétmintás $t$-próba vagy a Welch-féle $d$-próba eredménye)

\begin{tabular}{|c|c|c|c|c|c|c|c|c|c|}
\hline \multirow{3}{*}{$\begin{array}{c}\text { Mágikus } \\
\text { Fogalom- } \\
\text { képzés } \\
\text { Skála }\end{array}$} & \multirow{2}{*}{$\begin{array}{l}\text { Nor- } \\
\text { matív } \\
\text { minta }\end{array}$} & \multirow{3}{*}{$\begin{array}{l}\text { Klini- } \\
\text { kai } \\
\text { minta }\end{array}$} & \multirow[t]{3}{*}{$t(p)$} & \multicolumn{2}{|c|}{$\begin{array}{l}\text { Normatív } \\
\text { minta }\end{array}$} & \multirow[t]{3}{*}{$t(p)$} & \multicolumn{2}{|c|}{$\begin{array}{l}\text { Klinikai } \\
\text { minta }\end{array}$} & \multirow[t]{3}{*}{$t(p)$} \\
\hline & & & & Nók & $\begin{array}{l}\text { Fér- } \\
\text { fiak }\end{array}$ & & Nók & $\begin{array}{l}\text { Fér- } \\
\text { fiak }\end{array}$ & \\
\hline & átlag (SD) & & & \multicolumn{2}{|c|}{ átlag (SD) } & & \multicolumn{2}{|c|}{ átlag (SD) } & \\
\hline \multicolumn{10}{|c|}{15 tételes rövidített változat } \\
\hline $\begin{array}{l}\text { Paranormális } \\
\text { hiedelmek } \\
\text { alskála }\end{array}$ & $\begin{array}{c}0,68 \\
(1,23)\end{array}$ & $\begin{array}{c}1,35 \\
(1,72)\end{array}$ & $\begin{array}{c}5,11 \\
(<0,001)\end{array}$ & $\begin{array}{c}0,63 \\
(1,19)\end{array}$ & $\begin{array}{c}0,80 \\
(1,13)\end{array}$ & $\begin{array}{c}2,58 \\
(0,010)\end{array}$ & $\begin{array}{c}1,35 \\
(1,69)\end{array}$ & \begin{tabular}{|c|}
1,35 \\
$(1,81)$
\end{tabular} & $\begin{array}{c}0,01 \\
(0,991)\end{array}$ \\
\hline $\begin{array}{l}\text { Mágikus okság } \\
\text { és spiritualitás } \\
\text { alskála }\end{array}$ & $\begin{array}{c}2,77 \\
(1,92)\end{array}$ & $\begin{array}{c}2,86 \\
(2,12)\end{array}$ & $\begin{array}{c}0,58 \\
(0,560)\end{array}$ & $\begin{array}{c}3,00 \\
(1,93)\end{array}$ & $\begin{array}{c}2,29 \\
(1,80)\end{array}$ & $\begin{array}{c}7,39 \\
(<0,001)\end{array}$ & $\begin{array}{c}3,06 \\
(2,09)\end{array}$ & $\begin{array}{c}2,35 \\
(2,13)\end{array}$ & $\begin{array}{c}2,04 \\
(0,043)\end{array}$ \\
\hline $\begin{array}{l}\text { Mágikus } \\
\text { Fogalomképzés } \\
\text { Skála }\end{array}$ & $\begin{array}{c}3,46 \\
(2,64)\end{array}$ & $\begin{array}{c}4,21 \\
(3,41)\end{array}$ & $\begin{array}{c}2,90 \\
(0,004)\end{array}$ & $\begin{array}{c}3,63 \\
(2,60)\end{array}$ & $\begin{array}{c}3,10 \\
(2,69)\end{array}$ & $\begin{array}{c}3,92 \\
(<0,001)\end{array} \mid$ & $\begin{array}{c}4,41 \\
(3,32)\end{array}$ & $\begin{array}{c}3,70 \\
(3,61)\end{array}$ & $\begin{array}{c}1,26 \\
(0,208)\end{array}$ \\
\hline \multicolumn{10}{|c|}{30 tételes eredeti változat } \\
\hline $\begin{array}{l}\text { Mágikus } \\
\text { Fogalomképzés } \\
\text { Skála }\end{array}$ & \begin{tabular}{|l|}
8,44 \\
$(3,92)$
\end{tabular} & $\begin{array}{c}9,19 \\
(5,44)\end{array}$ & $\begin{array}{c}1,08 \\
(0,072)\end{array}$ & $\begin{array}{c}8,58 \\
(3,92)\end{array}$ & \begin{tabular}{|c|}
8,15 \\
$(3,93)$
\end{tabular} & \begin{tabular}{|c|}
2,09 \\
$(0,037)$
\end{tabular} & \begin{tabular}{|c|}
9,46 \\
$(5,36)$
\end{tabular} & \begin{tabular}{|c|}
8,47 \\
$(5,65)$
\end{tabular} & $\begin{array}{c}1,11 \\
(0,267)\end{array}$ \\
\hline
\end{tabular}

Az életkorral sem a normatív, sem a klinikai mintán egyetlen skála sem mutatott jelentős mértékú korrelációt. A legerősebb, statisztikai értelemben mégis igen gyenge együttjárást az életkorral a normatív mintán a Paranormális hiedelmek alskála esetében kaptuk $(r=-0,12 ; p<0,001)$, míg a klinikai 
mintán a Mágikus okság és spirituális alskálán $(r=-0,14 ; p=0,055)$. A normatív mintán a Mágikus Fogalomképzés Skála (15 és 30 tételes változat) enyhe, negatív irányú együttjárást mutatott az életkorral (15 tételes változat: $r=-0,04 ; p=0,049 ; 30$ tételes változat: $r=-0,07 ; p=0,003)$. Összességében elmondható, hogy a Paranormális hiedelmek az életkor előrehaladtával enyhe csökkenést mutatnak, míg a klinikai mintán a Mágikus okság és spiritualitás mutat hasonlóan enyhe negatív kapcsolatot. Meg kell azonban jegyeznünk, hogy a nagy elemszám miatt a normatív mintán ez a kapcsolati mutató szignifikáns, míg a klinikai mintán csak tendenciaszintú.

A következókben a Mágikus Fogalomképzés Skála rövid és teljes változatának együttjárásait szemléltetjük más pszichológiai konstruktumokkal a normatív mintát alapul véve. A rövid változat esetében a Paranormális hiedelmek és a Mágikus okság és spiritualitás alskálák közötti korreláció viszonylag alacsony $(r=0,37 ; p<0,001)$, ami azt jelzi, hogy a két skála eltéró konstruktumot takar (6. táblázat). A 15 tételból álló Mágikus fogalomképzés skála az eredeti 30 tételes változattal viszont magas együttjárást ad $(r=0,88$; $p<0,001)$, ami a két konstruktum ekvivalenciáját jelzi.

A mágikus gondolkodás skáláinak más mérőeszközökkel lefolytatott korrelációs vizsgálatával arra voltunk kíváncsiak, hogy mennyire támasztják alá az alskálák vagy a főskála érvényességét a más konstruktumokkal való összefüggések. A Paranormális hiedelmek és a Mágikus okság és spiritualitás dimenziók jól megkülönböztethetők az inadaptív és adaptív jellemzők mentén. A Paranormális hiedelmek alskála többnyire az inadaptív funkciókat jelző konstruktumokkal mutatott szoros $(r \geq 0,50)$ együttjárást, míg a Mágikus okság és spiritualitás dimenzió rendszerint az adaptív jellemzőkkel (6. táblázat). Jól megragadható ez például a Davis-féle Empátia Kérdőív Kognitív és Affektív skálákkal mutatott együttjárások összevetésénél, amikor a Mágikus gondolkodás és spiritualitás skála nagyságrendjét tekintve erősebb kapcsolatot jelez, mint amit a Paranormális hiedelmek esetében láthatunk. Közel hasonló eredményt találunk a Tellegen Abszorpciós Skálával történő összevetéskor is. Bár a Szkizotípia Személyiség Kérdőív összpontszámával a Mágikus okság és spiritualitás alskála adott erősebb együttjárást, ennek ellenére a skálák részletes vizsgálatakor azt láthatjuk, hogy több súlyosabb problémát megjelenítő alskála esetében a Paranormális jelenségek alskála ad szorosabb együttjárást. Érdemes kiemelni, hogy a Szkizotípia Személyiség Kérdőív Mágikus gondolkodás alskálája a Mágikus okság és spiritualitás alkálával mutat jelentős együttjárást, ami a vizsgált konstruktumunk érvényességét támasztja alá. Látható, hogy a 15 tételes változat Mágikus fogalomképzés skálája a nagyságrendjét tekintve szorosabb együttjárást ad a Szkizotípia Személyiség Kérdőív Mágikus gondolkodás skálájával, mint a 30 tételes változat. 
6. táblázat. A Mágikus Fogalomképzés Skála összevetése más mérőeszközökkel (Pearson-féle korrelációs együtthatók)

\begin{tabular}{|c|c|c|c|c|}
\hline & \multicolumn{2}{|c|}{$\begin{array}{l}15 \text { tételes } \\
\text { rövid változat }\end{array}$} & \multicolumn{2}{|c|}{$\begin{array}{c}30 \text { tételes } \\
\text { változat }\end{array}$} \\
\hline & 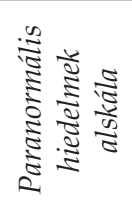 & 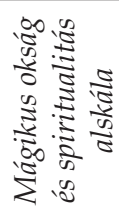 & 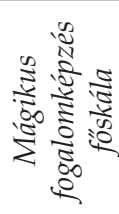 & 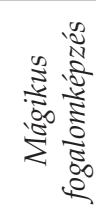 \\
\hline \multicolumn{5}{|c|}{ Mágikus Fogalomképzés Skála (15 tételes változat) } \\
\hline Paranormális hiedelmek alskála & & $0,37^{* *}$ & $0,74^{* *}$ & $0,67^{* *}$ \\
\hline Mágikus okság és spiritualitás alskála & & & $0,90 * *$ & $0,77^{* *}$ \\
\hline Mágikus fogalomképzés skála & & & & $0,88^{* *}$ \\
\hline \multicolumn{5}{|l|}{ Davis-féle Empátia Kérdőív $\left(n=761^{\mathrm{a}}\right)$} \\
\hline Kognitív & $0,15^{\star *}$ & $0,31^{* *}$ & $0,29 * *$ & 0,26 ** \\
\hline Affektív & 0,04 & $0,25^{* *}$ & $0,20 * *$ & $0,14^{* *}$ \\
\hline Nézőpontfelvétel & 0,01 & $0,11^{* *}$ & $0,08^{*}$ & $0,07^{*}$ \\
\hline Fantázia & $0,20^{* *}$ & $0,34^{* *}$ & $0,34^{* *}$ & $0,30^{* *}$ \\
\hline Empátiás törődés & $-0,03$ & $0,17^{* *}$ & $0,11^{* *}$ & 0,05 \\
\hline Személyes distressz & $0,08^{*}$ & $0,21^{* *}$ & $0,17^{* *}$ & $0,16^{* *}$ \\
\hline Tellegen Abszorpciós Skála $(n=1633)$ & $0,34^{* *}$ & $0,48^{* *}$ & $0,51^{* *}$ & $0,49^{* *}$ \\
\hline \multicolumn{5}{|l|}{ Szkizotípia Személyiség Kérdőív $(n=1730)$} \\
\hline Társas (negatív tünetek) & $0,13^{* *}$ & $0,11^{* *}$ & $0,15^{* *}$ & $0,16^{* *}$ \\
\hline Kognitív (pozitív tünetek) & $0,38^{* *}$ & $0,53^{* *}$ & $0,56 * *$ & $0,51^{* *}$ \\
\hline Diszorganizált & $0,28^{* *}$ & $0,26^{* *}$ & $0,32^{* *}$ & $0,33^{* *}$ \\
\hline Gyanakvás & $0,18^{* *}$ & $0,17^{* *}$ & $0,21^{* *}$ & $0,19 * *$ \\
\hline Közeli barátok hiánya & $0,09^{* *}$ & $0,05^{*}$ & $0,08^{* *}$ & $0,09 * *$ \\
\hline Furcsa viselkedés & $0,26^{* *}$ & $0,19 * *$ & 0,26 ** & $0,29 * *$ \\
\hline Szociális szorongás & $0,09^{* *}$ & $0,13^{* *}$ & $0,14^{* *}$ & $0,15^{* *}$ \\
\hline Mágikus gondolkodás & $0,22^{* *}$ & $0,55^{* *}$ & $0,50 * *$ & $0,42^{* *}$ \\
\hline Furcsa beszéd & $0,19 * *$ & $0,24^{* *}$ & $0,26 * *$ & $0,26^{* *}$ \\
\hline Szokatlan élmények iránti vonzalom & $0,40^{* *}$ & $0,34^{* *}$ & $0,43^{* *}$ & $0,42^{* *}$ \\
\hline
\end{tabular}

Megjegyzés: * $p<0,05 ;{ }^{* *} p<0,01$. a : A Davis-féle Empátia Kérdőív csak kisebb egy részmintán került felvételre. 


\section{Megbeszélés}

A hazai tudományos közlemények jelentős hányada tartalmaz mérőeszközadaptációt. Az adaptálás során sokszor olyan régebbi fejlesztésú módszereket kell hazai környezetre átültetni, amelyek a modern pszichometriai elvárásoknak csak részben felelnek meg. Mivel a tételek száma adott, így az adaptáció során általában a gyengébb pszichometriai tulajdonságokkal rendelkező tételek elhagyásával alakítunk ki rövidített változatot. A gyengébb pszichometriai tulajdonságokkal rendelkező tételek azonosítása a kutatási gyakorlatban leginkább a faktorszerkezet alapján történik, sokszor jelentős kihívást jelentve a kutatók számára. Nehézséget jelent, hogy a változók normalitásának sérülése miatt csak speciális módszerek alkalmazhatóak, a modern megerősítő faktorelemzések érzékenyek a válaszadási stílusra vagy a válaszbeállítódásra, a néhány évtizede megfogalmazott tételek nyelvezete pedig sokszor tartalmi frissítést is igényelne.

Az elemzéseink során kapott eredményeink azt jelzik, hogy a Mágikus Fogalomképzés Skála a normatív mintán kétdimenziósnak, míg a klinikai mintán egydimenziósnak tekinthető. A normatív mintán végzett elemzéseink eredményei rávilágítottak arra, hogy az egészséges személyek esetében az adataink nem illeszkednek maradéktalanul az egydimenziós szerkezetre, és láthattuk, hogy az egydimenziós szerkezet az összvariancia meglehetősen kevés hányadát $(27,4 \%)$ magyarázza. Az átfogó faktorelemzések a normatív mintán három, míg a klinikai mintán két dimenziót valószínúsítettek. Mindkét minta esetében megjelent egy módszertani okra, a válaszbeállítódásra visszavezethető faktor, ami a negatív tételek önálló dimenzióba szerveződését eredményezte.

A válaszbeállítódásból fakadó faktort elhagyva, így a normatív mintán kétdimenziós, míg a klinikai mintán egydimenziós szerkezet bontakozott ki. A normatív mintán a Paranormális hiedelmek, illetve a Mágikus okság és spiritualitás dimenziókat azonosítottuk. Több tételt elhagytunk, vagy azért, mert nem rendelkezett jelentős faktorsúllyal egyetlen dimenzión sem, vagy pedig azért, mert egyidejúleg több faktorral is szoros együttjárást adott. A tételek ezen sajátosságait feltehetően a skálaszerkesztési technika eredményezte, mivel a méróeszköz kidolgozói (Eckblad \& Chapman, 1983) elsődleges célja a skála bejósló erejének növelése volt, így számos heterogén tartalmú tétel került a kérdőívbe. Eckblad és Chapman (1983) nem végeztek faktorelemzést, nem törekedtek a komponensek homogenizálására. Bár az elmúlt több mint 30 évben számos faktorelemzés készült a Mágikus Fogalomképzés Skálán (pl. Çam és mtsai, 2014; Cicero és mtsai, 2019; Fonseca-Pedrero és mtsai, 2009; Garzitto és mtsai, 2016; Horan és mtsai, 2004; Johnston, 1991; Winterstein és mtsai, 2011a; Winterstein és mtsai, 2011b), de ezek nem eredményeztek látványos megoldásokat, mivel a meg- 
lévő 30 tétel jelentősen meghatározza a lehetséges dimenziók számát és tartalmát. A tételek elhagyásával, vagy aldimenziók létrehozásával a tételszámok csökkennek, ami a skálák reliabilitásának csökkenését eredményezi. A nagy elemszámú normatív vizsgálati mintánkon kialakított kétfaktoros struktúra a hagyományos pszichometriai követelményeknek megfelel, a skálák elfogadható belső konzisztenciával rendelkeznek. A bifaktoros elrendezés jól illeszthető az adatainkra, de láthatjuk azt is, hogy az alskálák modell alapú megbízhatósági becslései (hierarchikus ómega) alacsonyak. A két, egymástól jól elkülönülő alskála létrehozása szakmai értelemben nagyon hasznos, hiszen az egyik fóként a maladaptív sajátosságokkal jellemezhető, míg a másik inkább adaptív tulajdonságokkal rendelkezik. Azt gondoljuk, hogy a bifaktoros elrendezés jelzi, hogy az elsődlegesen maladaptívnak tekintett tételek között megtalálható egy olyan tételcsoport, amit az egészséges személyek is jellemzőnek tarthatnak önmagukra. Ezek a tételek az egészséges személyek esetében inkább egyfajta spirituális dimenziónak tekinthetőek. Sajnos ezen a ponton azonban nehéz továbblépni, vagy mélyebb következtetéseket levonni, hiszen számos módszertani korlát jelentkezik: pl. a bifaktoros modellek illeszkedési mutatói általában túlbecsülik a modell illeszkedését, a kiválasztott 15 tételból 9 a nemre vagy a mintatípusra nézve eltéró jelentést hordoz, a két alskála modellalapú megbízhatósága pedig alacsony, a több mint 30 éve megalkotott tételek ma már nem teljesen azt jelentik, mint a kidolgozáskor.

Úgy tûnik, hogy a normatív mintán ez a kettős elrendezés sokkal árnyaltabb lehetőséget biztosít a mágikus gondolkodás vizsgálatára, mint az egyetlen dimenzióból álló skála. Láthattuk, hogy a Mágikus okság és spiritualitás alskála átlagai nem térnek el szignifikánsan a normatív és a klinikai csoportok összevetésekor. A különböző faktorokhoz tartozó tételek tartami elemzése szintén alátámasztja a 15 tételes Mágikus fogalomképzés skála adaptív és maladaptív vonásokra vonatkozó kettősségét. A Paranormális hiedelmek alskála derealizációs jelenségeket tartalmaz, amelyekben a környezet téri és idői percepciójának sérülése következtében realitástorzulás, képzelt külső akarati és energiahatások befolyása alá kerülés élménye az uralkodó. Ezzel szemben a Mágikus okság és spiritualitás alskála esetében a szokatlan élmények átélése, gondolatok és vágyak tárgyakra való kivetítése, a környezet fokozott perszonalizációja, az ismeretlen eredetú eseményekre vonatkozó adaptív viselkedéskészlethez tartozó (sokszor kreatív eredményre vezető) jelentésgenerálás dominál.

Az egyes tételek részletes, valószínúségi tesztelméleten alapuló elemzésének eredménye részben megerősítette a 15 tételes rövid változat érvényességét (pl. diszkrimináció és nehézség), de jelezte azt is, hogy néhány tételt eltérő múködés jellemez a nők és férfiak, vagy a normatív és klinikai minták összevetésekor. Az itemparaméterek egyértelmúen mutatják, hogy a legtöbb tétel inkább a mágikus fogalomképzés magasabb tartományaiban 
múködnek, míg az átlagos vagy átlag alatti övezetekben kevéssé várhatóak a tételekre igen válaszok. Mindez alapján a mérőeszköz használata inkább klinikai mintán ajánlott.

A klinikai mintán történő elemzések során láthattuk, hogy az egydimenziós mérőeszköz az eredeti 30 tételes változatában is jó pszichometriai tulajdonságokkal rendelkezik. Bár a mérőeszköz diagnosztikai megbízhatóságát nem állt módunkban vizsgálni, ennek ellenére a klinikai gyakorlatban alkalmazott 19 pontos cut-off pontszám alkalmazása a hazai mintán is elfogadható gyakoriságokat eredményezett. A klinikai mintánk 7\%-a került a fokozott szkizotípiás tüneteket jelentő kategóriába, míg a normatív mintánkból ez az arány kevesebb, mint $1 \%$.

A skála rövidítését az is indokolja, hogy néhány tétel megfogalmazása, jelentéstartalma napjainkra kevésbé aktuális (pl.10. A kormány megtagadja tőlünk az igazságot a repülő csészealjakról.; 13. A szerencsehozó talizmánok nem múködnek.; 14 . Néha észreveszek olyan hangokat is a felvételeken, amik máskor nincsenek ott.). Ezeket a tételeket csak komolyabb tartalmi módosításokkal lehetne aktualizálni, ami azonban már túlmutat az adaptáció keretein.

Érdemes megjegyezni, hogy kutatásunk során egy közel 700 fős egyetemi hallgatói mintán a 30 tételes Mágikus fogalomképzés skála 5-fokozatú Likert-skálás válaszlehetôségen alapuló változatát is kitöltettük. A válaszlehetőségek végpontjai a következők voltak: egyáltalán nem jellemzó [1] - nagyon jellemző [5]. Terjedelmi korlátok miatt ugyan ennek a vizsgáltnak az eredményeit nem ismertetjük a jelen tanulmányban, de összességében elmondható, hogy az ötfokozatú válaszlehetőségen alapuló változat a faktorszerkezetet vagy a reliabilitást illetően nem eredményezett lényegesen eltérő eredményt. Bár az 5-fokozatú válaszlehetóség a nagyobb tétel- és skálavarianciák miatt könnyebb elemezhetőséget ígért, ennek ellenére több tétel eloszlása esetében az láttuk, hogy a dichotóm (igen-nem) válaszlehetóség adekvátabb, mivel a közbülső értékeket néhány tétel esetében nem használták a kitöltők. A megfogalmazott kérdéseket leginkább az igen-nem válaszlehetőségeken lehet megítélni.

Az eredményeink azt sugallják, hogy a mágikus fogalomképzés nem helyezhetó el pontosan az adaptáció-inadaptáció kontinuum valamelyik extrém pólusán. Az egészséges és a pszichopatológiai zavaroktól szenvedó személyek vonatkozásában kiemelhetjük, hogy a mágikus gondolkodás a kulturális és az egyéni fejlődésmenet szempontjából egyaránt a valóság belső reprezentációjának megkonstruálására vonatkozó kognitív eljárásmód. A kulturantropológiai és fejlődéslélektani vizsgálatok eredményei egyértelmúvé tették, hogy a „mágikus” kifejezés ezekben az esetekben nem a misztikus jelenségek kezelésére, varázslatok kivitelezésére vonatkozó beállítódás, hanem a mentális fejlődés nélkülözhetetlen részét képező jelentést generáló kognitív folyamat (Piaget, 1957; Subbotsky, 2010). 
Eredményeink szerint a Mágikus Fogalomalkotás Kérdőív rövidített, 15 tételes változata normatív és klinikai mintán egyaránt megfelelő megbízhatósággal használható. Egészséges személyeknél a mágikus fogalomképzés konstruktumának két alskálája jó predikciót kínál a regresszív kognitív múveletek előjelzésére. Jelen vizsgálat ismereteink szerint a Mágikus Fogalomképzés Skálával végzett első, részletes klinikai mintán végzett pszichometriai elemzés, amely betekintést enged a szkizofrénia spektrum zavarba tartozó mentális betegségek kognitív komponenseinek részletesebb elemzésébe. Az adaptív, kreatív törekvések jelenlétének vizsgálata ugyanakkor az egészéges és klinikai populáció esetén tapasztalható gondolkodás különbségekre is rávilágít. Segítséget kínál a mágikus gondolatalkotás kreatív komponenseinek előtérbe állításán keresztül a rehabilitációs tevékenység megtervezéséhez. Kutatásunk fő korlátjaként a klinikai minta egy részét alkotó szkizofrénia spektrum zavar diagnózissal rendelkezók alacsony számát kell megemlítenünk, amely nem tette lehetővé, hogy az elemzéseinket célirányosan ezen a csoporton végezzük.

\section{Irodalom}

Acar, S., \& Sen, S. (2013). A multilevel meta-analysis of the relationship between creativity and schizotypy. Psychology of Aesthetics, Creativity, and the Arts, 7(3), 214-228.

Anderson, J.C., \& Gerbing, D.W. (1984). The effect of sampling error on convergence, improper solutions, and goodness-of-fit indices for maximum likelihood confirmatory factoranalysis. Psychometrika, 49, 155-173.

American Psychiatric Association. (2013). Diagnostic and statistical manual of mental disorders (5th ed.). Arlington, VA: American Psychiatric Association

Baker, F.B. (1985). The basics of item response theory. Portsmouth, NH: Heinemann

Bentler, P.M. (1990). Comparative fit indeces in structural models. Psychological Bulletin, 88, 588-606.

Bentler, P.M., \& Bonnet, D. C. (1980). Significance Tests and Goodness of Fit in the Analysis of Covariance Structures. Psychological Bulletin, 88(3), 588-606.

Brouwer, D., Meijer, R.R., \& Zevalkink, J. (2013). On the factor structure of the Beck Depression Inventory-II: G is the key. Psychological Assessment, 25, 136-145.

Browne, M.W., \& Cudeck, R. (1993). Alternative ways of assessing model fit. In K.A. Bollen \& J.S. Long (Eds.), Testing structural equation models (136-162). Newbury Park, CA: Sage.

Cai, L., Thissen, D., \& du Toit, S.H.C. (2011). IRTPRO for Windows. Lincolnwood, IL: Scientific Software International

Çam, Z., Seydooğulları, S., \& Artar, M. (2014). Psychometric properties of the magical ideation scale in high school adolescents. Dusunen Adam: The Journal of Psychiatry and Neurological Sciences, 27, 34-42.

Chapman, L.J., \& Chapman, J.P. (1987). The search for symptoms predictive of schizophrenia. Schizophrenia Bulletin, 13, 497-503.

Chapman, J.P., Chapman, L.J., \& Kwapil, T.R. (1995). Scales for the measurement of schizotypy. New York, NY: Cambridge University Press

Chapman, L.J., Chapman, J.P., Kwapil, T.R., Eckblad, M., \& Zinser, M.C. (1994). Putatively psychosis-prone subjects 10 years later. Journal of Abnormal Psychology, 103(2), 171-183. 
Chapman, L.J., Chapman, J.P., \& Miller, E.N. (1982). Reliabilities and intercorrelations of eight measures of proneness to psychosis. Journal of Consulting and Clinical Psychology, 50, 187-195.

Chapman, L.J., Chapman, J.P., \& Raulin, M.L. (1976). Scales for physical and social anhedonia. Journal of Abnormal Psychology, 85, 74-82.

Chapman, L.J., Chapman, J.P., \& Raulin, M.L. (1978). Body-image aberration in schizophrenia. Journal of Abnormal Psychology, 87, 399-407.

Chou, C., \& Bentler, P.M. (1995). Estimates and tests in structural equation modeling. In R. H. Hoyle (Ed.), Structural equation modeling: Concepts, issues, and applications (37-55). Thousand Oaks, CA: Sage

Cicero, D.C., Martin, E.A., \& Krieg, A. (2019). Differential item functioning of the full and brief Wisconsin Schizotypy Scales in Asian, white, Hispanic, and multiethnic samples and between sexes. Assessment, 26(6), 1001-1013.

Claridge, G. (1997). Schizotypy: implication for illness and heath. New York, Oxford University Press.

Cohen, A.S., Matthewa, R., Najolia, G., \& Brown, L.A. (2010). Toward a more psychometricallysound brief measure of schizotypy improving the SPQ-B. Journal of Personality Disorders, 24, 516-537.

Cole, D.A. (1987). Utility of confirmatory factor analysis in test validation researh. Journal of Consulting and Clinical Psychology, 55, 584-594.

Curran, P.J., West, S.G., \& Finch, J.F. (1996). The robustness of test statistics to nonnormality and specification error in confirmatory factor analysis. Psychological Methods, 1, 16-29.

Davis, M.H. (1983). Measuring individual differences in empathy: Evidence for a multidimensional approach. Journal of Personality and Social Psychology, 44, 113-126.

Drasgow, F., \& Parsons, C.K. (1983). Application of unidimensional item response theory models to multidimensional data. Applied Psychological Measurement, 7, 189-199.

Dumas, P., Bouafia, S., Gutknecht, C., Saoud, M., Daléry, J., \& d'Amato, T. (2000). Validations des versions françaises des questionnaires d'idéation magique (MIS) et d'aberrations perceptives (PAS) [Magical Ideation Scale (MIS) and Perceptual Aberration Scale (PAS): Validations of the French translations in a sample of 233 French students]. L'Encéphale: Revue de psychiatrie clinique biologique et thérapeutique, 26(4), 42-46.

Eckblad, M., Chapman, L.J., Chapman, J.P., \& Mishlove, M. (1982). The Revised Social Anhedonia Scale. Unpublished manuscript. Madison: University of Wisconsin

Eckblad, M., \& Chapman, L.J. (1983). Magical ideation as an indicator of schizotypy. Journal of Consulting and Clinical Psychology, 51(2), 215-225.

Edell, W.S. (1995). The psychometric measurement of schizotypy using the Wisconsin scales of psychosis proneness. In: Miller GA, editor. Behavioral high-risk paradigm psychopathology (3-46). New York, NY: Springer Publishing

Einstein, D.A., \& Menzies, R.G. (2004). The presence of magical thinking in obsessive compulsive disorder. Behaviour Research and Therapy, 42(5), 539-549.

Elek, Zs., Rónai, Zs., Hargitai, R., Hartung, I., Réthelyi, J., Arndt, B., et al. (in press). Magical thinking and social anxiety as a bio-psychological developmental disposition for cognitive and affective symptom intensity in schizotypy: traits and genetic associations. PeerJ.

Fejes, N.É., Rózsa, S., \& Must, A. (2018). Szkizotíp személyiségvonások és a nyelvi kreativitás összefüggéseinek vizsgálata. Ideggyógyászati Szemle, 71(3-4), 113-125.

Flückiger, R., Ruhrmann, S., Debbané, M., Michel, C., Hubl, D., Schimmelmann, B.G., \& Schultze-Lutter, F. (2016). Psychosis-predictive value of self-reported schizotypy in a clinical high-risk sample. Journal of Abnormal Psychology, 125(7), 923-932. 
Fonseca-Pedrero, E., Paíno, M., Lemos-Giráldez, S., García-Cueto, E., Campillo-Álvarez, Á., Villazón-García, Ú., et al. (2008). Schizotypy assessment: state of the art and future prospects. Clinical Health Psychology, 8, 577-593.

Fonseca-Pedrero, E., Paino, M., Lemos-Giráldez, S., García-Cueto, E., Villazón-García, Ú., \& Muñiz, J. (2009). Psychometric properties of the Perceptual Aberration Scale and the Magical Ideation Scale in Spanish college students. International Journal of Clinical and Health Psychology, 9(2), 299-312.

García-Batista, Z.E., Guerra-Peña, K., Cano-Vindel, A., Herrera-Martínez, S.X., \& Medrano, L.A. (2018). Validity and reliability of the Beck depression inventory (BDI-II) in general and hospital population of Dominican Republic. PloS One, 13(6). e0199750. doi:10.1371/ journal.pone.0199750

Garzitto, M., Picardi, A., Fornasari, L., Gigantesco, A., Sala, M., Fagnani, C., et al. (2016). Normative data of the Magical Ideation Scale from childhood to adulthood in an Italian cohort. Comprehensive Psychiatry, 69, 78-87.

Gignac, G.E., \& Watkins, M.W. (2013). Bifactor modeling and the estimation of model-based reliability in the WAIS-IV. Multivariate Behavioral Research, 48(5), 639-662.

Gooding, D.C., Tallent, K.A., \& Matts, C.W. (2005). Clinical status of at-risk individuals 5 years later: Futher validation of the psychometric high-risk strategy. Journal of Abnormal Psychology, 114, 170-175.

Grant, P., Green, M.J., \& Mason, O.J. (2018). Models of schizotypy: the importance of conceptual clarity. Schizophrenia Bulletin, 44(S2), 556-563.

Graves, R.E., \& Weinstein, S. (2004). A rasch analysis of three of the Wisconsin scales of psychosis proneness: measurement of schizotypy. Journal of Applied Measurement, 5, 160-171.

Hanssen, M., Peeters, F., Krabbendam, L., Radstake, S., Verdoux, H., \& van Os, J. (2003). How psychotic are individuals with non-psychotic disorders? Social Psychiatry, Psychiatric Epidemiology, 38, 149-154.

Harvey, R.J., Billings, R.S., \& Nilan, K.J. (1985). Confirmatory factor analysis of the job diagnostic survey: Good news and bad news. Journal of Applied Psychology, 70, 461-468.

Horan, W.P., Blanchard, J.J., Gangestad, S.W., \& Kwapil, T.R. (2004). The psychometric detection of schizotypy: do putative schizotypy indicators identify the same latent class? Journal of Abnormal Psychology, 113(3), 339-357.

IBM Corp. (2013). IBM SPSS Statistics for Windows, Version 22.0. Armonk, NY: IBM Corp. Idaszak, J., \& Drasgow, F. (1987). A revision of the job diagnostic survey: Elimination of a measurement artifact. Journal of Applied Psychology, 72, 69-74.

Johnston, L.A. (1991). The use of the magical ideation scale to measure magical thinking. Doctoral thesis. Carleton University. Letöltve: 2019. 09. 22-én: https:/ / curve.carleton. ca/75144633-0022-436a-a3ea-6641feb77497

Jöreskog, K., \& Sörbom, D. (1993). LISREL 8: Structural Equation Modeling with the SIMPLIS Command Language. Chicago, IL: Scientific Software International Inc.

Kállai, J., Rózsa, S., Hupuczi, E., Hargitai, R., Birkás, B., Hartung, I., et al. (2018). A Szkizotípia Személyiség Kérdőív rövid, módosított változatának (SPQ-BR) magyar adaptációja és faktorainak értelmezése. Psychiatria Hungarica, 33(3), 205-221.

Kelleher, I., Keeley, H., Corcoran, P., Lynch, F., Fitzpatrick, C., Devlin, N., et al. (2012). Clinicopathological significance of psychotic experiences in non-psychotic young people: evidence from four population-based studies. British Journal of Psychiatry, 201(1), 26-32.

Khoshouei, M.S. (2008). Psychometric properties of the Persian Version of the Magical Ideation Scale (MIS) in university students. International Journal of Psychology, 2(1), 49-60. 
Kihlstrom, J.F., Register, P.A., Hoyt, I.P., Albright, J.S., Grigorian, E.M., \& Heindel, W.C. (1989). Dispositional correlates of hypnosis: A phenomenological approach. International Journal of Clinical and Experimental Hypnosis, 37, 249-263.

Kingdon, B.L., Egan, S.J., \& Rees, C.S. (2011). The Illusory Beliefs Inventory: A new measure of magical thinking and its relationship with obsessive compulsive disorder. Behavioural and Cognitive Psychotherapy, 40(1), 39-53.

Kulcsár, Zs. (2002). Egészségpszichológia. Budapest: ELTE Eötvös Kiadó

Kwapil, T.R., Barrantes-Vidal, N., \& Silvia, P.J. (2008). The dimensional structure of the Wisconsin schizotypy scales: factor identification and construct validity. Schizophrenia Bulletin, 34, 444-457.

Kwapil, T.R., Gross, G.M., Silvia, P.J., \& Barrantes-Vidal, N. (2013). Prediction of psychopathology and functional impairment by positive and negative schizotypy in the Chapmans' ten-year longitudinal study. Journal of Abnormal Psychology, 122, 807-815.

Kwapil, T.R. (1998). Social Anhedonia as a predictor of the development of schizophreniaspectrum disorders. Journal of Abnormal Psychology, 107, 558-565.

Lavender, A., Shubert, I., Silva, P., \& Treasure, J. (2006). Obsessive-compulsive beliefs and magical ideation in eating disorders. British Journal of Clinical Psychology, 45(3), 331-342.

Lewandowski, K.E., Barrantes-Vidal, N., Nelson-Gray, R.O., Clancy, C., Kepley, H.O., \& Kwapil, T.R. (2006). Anxiety and depression symptoms in psychometrically identified schizotypy. Schizophrenia Research, 83, 225-235.

Lorenzo-Seva, U., \& Ferrando, P.J. (2006). FACTOR: A computer program to fit the exploratory factor analysis model. Behavior Research Methods, 38(1), 88-91.

Lorenzo-Seva, U., \& Ferrando, P.J. (2013). FACTOR 9.2 A comprehensive program for fitting exploratory and semiconfirmatory factor analysis and IRT models. Applied Psychological Measurement, 37(6), 497-498.

Lyons, M.J., Toomey, R., Faraone, S.V., Kremen, W.S., Yeung, A.S., Tsuang, \& M.T. (1995). Correlates of psychosis proneness in relatives of schizophrenic patients. Journal of Abnormal Psychology, 104(2), 390-394.

Marsh, H.W., Balla, J.R., \& McDonald, R.P. (1988). Goodness-of-fit indexes in confirmatory factoranalysis: The effects of sample size. Psychological Bulletin, 103, 305-312.

McDonald, R.P. (1999). Test theory: A unified treatment. Mahwah, NJ: Lawrence Erlbaum

McIntosh, C. (2006). Rethinking fit assessment in structural equation modeling: A commentary and elaboration on Barrett (2007), Personality and Individual Differences, 42 (5), 859-67.

Meehl, P.E. (1962). Schizotaxia, schizotypy, schizophrenia. American Psychologist, 17(12), 827-838.

Meehl P.E. (1964). Manual for use with Checklist of Schizotypic Signs (No. PR-73-5). Minneapolis, MN: University of Minnesota, Research Laboratories of the Department of Psychiatry

Miettunen, J., Veijola, J., Isohanni, M., Paunio, T., Freimer, N., Jääskeläinen, E., et al. (2011). Identifying schizophrenia and other psychoses with psychological scales in the general population. The Journal of Nervous and Mental Disease, 199(4), 230-238.

Miller, A., \& Ellen-Miller, A. (1989). From rituals to the repertoire. Cognitive-Developmental systems approach with behavioral-disordered children. New York: Willey and Sons

Morizot, J., Ainsworth, A.T., \& Reise, S.P. (2009). Toward modern psychometrics: application of item response theory models in Personlaity research. In R.W. Robins, R.C. Fraley, \& R.F. Krueger (Eds.), Handbook of Research Methods in Personality Psychology (407-421). New York, NY: Guilford Press

Muthén, L.K., \& Muthén, B.O. (1998-2017). Mplus User's Guide. Eighth Edition. Los Angeles, CA: Muthén \& Muthén 
Muthén, B.O., \& Kaplan, D. (1985). A comparison of some methodologies for the factor analysis of nonnormal Likert variables. British Journal of Mathematical and Statistical Psychology, 38, 171-189.

Niemyjska, A. (2015). How does love magic work? The regulation of closeness and affect by magical thinking. Journal of Social and Personal Relationships, 32(1), 57-77.

Piaget, J. (1957). Construction of reality in the child. London: Routledge \& Kegan Paul

Polner, B., Simor, P., Kéri, S. (2018). Insomnia and intellect mask the positive link between schizotypal traits and creativity. Peer Journal, 6:e5615. Doi: 10.7717/ peerj.5615

Rado, S. (1953). Dynamics and classification of disordered behavior. American Journal of Psychiatry, 110, 406-416.

Reise, S.P. (2012). The rediscovery of bifactor measurement models. Multivariate Behavioral Research, 47, 667-696.

Ross, S.R., Lutz, C.J., \& Bailley, S.E. (2002). Positive and negative symptoms of schizotypy and the Five-Factor Model: A domain and facet level analysis. Journal of Personality Assessment, 79, 53-72.

Rózsa, S., Hupuczi, E., Martin, L., Birkás, B., Hartung, I., Hargitai, R., et al. (2019). A Tellegen Abszorpciós Skála részletes pszichometriai elemzése. Mentalhigiéné és Pszichoszomatika, 20(1), 35-77.

Ropovik, I. (2015). A cautionary note on testing latent variable models. Frontiers in Psychology, 6:1715. Doi: 10.3389/fpsyg.2015.01715

Scherbarth-Roschmann, P., \& Hautzinger, M. (1991). Zur psychometrischen Erfassung von Schizo typie: Methodische Überprüfung und erste Validierung von zwei Skalen zur Erfassung von Risikomerkmalen. Zeitschrift für Klinische Psychologie, 20, 238-250.

Schmitt, N., \& Stults, D.M. (1986). Methodology review: Analysis of multitrait-multimethod matrices. Applied Psychological Measurement, 10, 1-22.

Shafran, R., \& Rachman, S., 2004. Thought-action fusion: a review. Journal of Behavior Therapy and Experimental Psychiatry, 35, 87-107.

Shah, J., Eack, S.M., Montrose, D.M., Tandon, N., Miewald, J.M., Prasad, K.M., et al. (2012). Multivariate prediction of emerging psychosis in adolescents at high risk for schizophrenia. Schizophrenia Research, 141(2-3), 189-196.

Simor, P., Köteles, F., \& Bódizs, R. (2011). Elmerülés az élményben: a Tellegen-féle Abszorpció Skála vizsgálata egyetemista mintán. Mentálhigiénéés Pszichoszomatika, 12(2), 101-123.

Smith, A. (2006). Cognitive empathy and emotional empathy in human behavior and evolution. Psychological Record, 56, 3-21.

Steiger, J.H. (1990). Structural model evaluation and modification: An interval estimation approach. Multivariate Behavioral Research, 25(2), 173-180.

Stip, E., Corbière, M., Boulay, L. J., Lesage, A., Lecomte, T., Leclerc, C., et al. (2007). Intrusion errors in explicit memory: Their differential relationship with clinical and social outcome in chronic schizophrenia. Cognitive Neuropsychiatry, 12(2), 112-127.

Stucky, B.D., \& Edelen, M.O. (2014). Using hierarchical IRT models to create unidimensional measures from multidimensional data. In S.P. Reise \& D.A. Revicki (Eds.), Handbook of item response theory modeling: Applications to typical performance assessment (183-206). London, UK: Taylor \& Francis

Subbotsky, E. (2010). Magic and the Mind: mechanisms, functions and development of magical thinking and behavior. Oxford: Oxford University Press

Tabachnick, B.G., \& Fidell, L.S. (2007). Using multivariate statistics (5th ed.). New York: Allyn and Bacon

Tanaka, J.S. (1993). Multifaceted conceptions of fit in structural equations models. In K.A. Bollen \& J.S. Long (Eds.), Testing structural equation models (10-39). Newbury Park, CA: Sage 
Te Wildt, B.T., \& Schultz-Venrath, U. (2004). Magical ideation - defense mechanism or neuropathology? Psychopathology, 37(3), 141-144.

Tellegen, A. (1982). Content categories: Absorption items (revised). Unpublished manuscript. Minneapolis: University of Minnesota

Tellegen, A., \& Atkinson, G. (1974). Openness to absorbing and self-altering experiences („,absorption"), a trait related to hypnotic susceptibility. Journal of Abnormal Psychology, 83(3), 268-277.

Tucker, L.R., \& Lewis, C. (1973). A reliability coefficient for maximum likelihood factor analysis. Psychometrika, 38(1), 1-10.

Urbán, R., Kun, B., Farkas, J., Paksi, B., Kökönyei, G., Unoka, Z., et al. (2014). Bifactor structural model of symptom checklists: SCL-90-R and Brief Symptom Inventory (BSI) in a non-clinical community sample. Psychiatry Research, 216(1), 146-154.

Utināns, A. (2015). Change of ratio of magical thinking, paranormal beliefs and critical thinking disposition in medical study process. Doctoral Thesis. Riga: Rigas Stradina Universitate

Vieira, P.G., Villemor-Amaral, A.E., \& Pianowski, G. (2016). Tradução, Adaptação e Evidências Iniciais de Validade da Magical Ideation Scale, Psicologia: Teoria e Pesquisa, 32(4), 1-7.

Watkins, M.W. (2010). Structure of the Wechsler Intelligence Scale for Children - Fourth Edition among a national sample of referred students. Psychological Assessment, 22, 782-787.

Werner, H. (1948). Comparative psychology and mental development. Oxford: Follett Pub. Co.

West, B., \& Willner, P. (2011). Magical thinking in obsessive-compulsive disorder and generalized anxiety disorder. Behavioural and Cognitive Psychotherapy, 39(4), 399-411.

Wheaton, B., Muthen, B., Alwin, D.F., \& Summers, G. (1977). Assessing reliability and stability in panel models, Sociological Methodology, 8(1), 84-136.

Winterstein, B.P., Ackerman, T.A., Silvia, P.J., \& Kwapil, T.R. (2011a). Psychometric properties of the Wisconsin Schizotypy Scales in an undergraduate sample: classical test theory, item response theory, and differential item functioning. Journal of Psychopathology and Behavioral Assessment, 33(4), 480-490.

Winterstein, B.P., Silvia, P.J., Kwapil, T.R., Kaufman, J.C., Reiter-Palmon, R., \& Wigert, B. (2011b). Brief assessment of schizotypy: Developing short forms of the Wisconsin Schizotypy Scales. Personality and Individual Differences, 51(8), 920-924.

Winterstein, B.P., Willse, J.T., Kwapil, T.R., Silvia, P.J. (2010). Assessment of score dependability of the Wisconsin schizotypy scales using generalizability analysis. Journal of Psychopathology and Behavioral Assessment, 32, 575-585,

Woods, C.M. (2006). Careless responding to reverse-worded items: Implications for confirmatory factor analysis. Journal of Psychopathology and Behavioral Assessment, 28(3), 186-191.

Woolley, J.D. (2000). The development of beliefs about direct mental-physical causality in imagination, magic, and religion. In K.S. Rosengren, C.N. Johnson, \& P.L. Harris (Eds.), Imagining the impossible: Magical, scientific, and religious thinking in children (99-129). Cambridge: Cambridge University Press

Zhong, W., Krueger, F., Wilson, M., Bulbulia, J., \& Grafman, J. (2018). Prefrontal brain lesions reveal magical ideation arises from enhanced religious experiences. Peace and Conflict: Journal of Peace Psychology, 24(2), 245-249. 


\section{Köszönetnyilvánítás}

A vizsgálatok elvégzését az NKFI K-120334 számú pályázata támogatta. Rózsa Sándort a tanulmány elkészítésében a Károli Gáspár Református Egyetem 20643B800 témaszámú, Személy és családorientált egészségtudomány kutatócsoport számára adott pályázat támogatta. A szerzők ezúttal mondanak köszönetet a kézirat ismeretlen lektorainak és a folyóirat felelős szerkesztőjének az értékes megjegyzésekért és javaslatokért, amelyek nagyban segítették a cikk végső változatának kialakítását.

\section{Szerzói munkamegosztás}

Rózsa Sándor: adatelemzési stratégia kialakítása, statisztikai elemzések, eredmények értelmezése, kézirat megszövegezése. Hupuczi Ernő: statisztikai elemzések. Martin László: adatgyújtés és ellenőrzés, az eredmények értelmezése. Hartung István: adatgyújtés és hipotézisalkotás. Hargitai Rita: adatgyújtés lefolytatása, a tanulmány szövegezése. Vincze Gábor és Török I. András: vizsgálat előkészítése, adatgyújtés, eredmények értelmezése. Simon Mária: konceptualizálás, adatgyújtés. Tiringer István: adatgyújtés és ellenőrzés, eredmények értelmezése. Kállai János: kutatási terv és kutatási hipotézisek kidolgozása, eredmények értelmezése, kézirat megszövegezése.

\section{Nyilatkozat érdekütközésról}

A szerzők ezúton kijelentik, hogy esetükben nem állnak fenn érdekütközések. 


\section{Függelék: Mágikus Fogalomképzés Skála}

Kérjük, hogy az „Igen” vagy a „Nem” válasz megjelölésével válaszoljon minden állításra.

\begin{tabular}{|c|c|c|}
\hline & Igen & Nem \\
\hline $\begin{array}{l}\text { 1. Néhány emberról már azáltal tudomást szerzek, hogy rám } \\
\text { gondolnak. }\end{array}$ & & \\
\hline 2. Volt már olyan érzésem, hogy talán nem is vagyok emberi lény. & & \\
\hline 3. Előfordult, hogy féltem rálépni a járda repedéseire. & & \\
\hline 4. Szerintem képes lennék mások elméjében olvasni, ha akarnám. & & \\
\hline $\begin{array}{l}\text { 5. A horoszkópok túl gyakran igazak ahhoz, hogy véletlenek } \\
\text { legyenek. }\end{array}$ & & \\
\hline $\begin{array}{l}\text { 6. Mikor hazaérek, néha úgy túnik, a dolgok más helyre kerültek, } \\
\text { annak ellenére, hogy senki sem járt ott. }\end{array}$ & & \\
\hline $\begin{array}{l}\text { 7. Bizonyos számok, mint például a } 13 \text { és } 7 \text { semmilyen különleges } \\
\text { erővel nem rendelkeznek. (R) }\end{array}$ & & \\
\hline $\begin{array}{l}\text { 8. Néha volt már olyan furcsa érzésem, hogy a rádiós vagy tévés } \\
\text { músorvezető tudta, hogy hallgatom őt. }\end{array}$ & & \\
\hline $\begin{array}{l}\text { 9. Aggódtam már amiatt, hogy más bolygókon élő emberek } \\
\text { befolyásolhatják azt, ami a Földön történik. }\end{array}$ & & \\
\hline $\begin{array}{l}\text { 10. A kormány megtagadja tőlünk az igazságot a repülő } \\
\text { csészealjakról. }\end{array}$ & & \\
\hline $\begin{array}{l}\text { 11. Éreztem már azt, hogy a tárgyak elrendezése, például egy } \\
\text { kirakat berendezése üzenetet közvetít számomra. }\end{array}$ & & \\
\hline $\begin{array}{l}\text { 12. Soha nem kételkedtem abban, hogy az álmaim a saját elmém } \\
\text { szüleményei. (R) }\end{array}$ & & \\
\hline 13. A szerencsehozó talizmánok nem múködnek. (R) & & \\
\hline $\begin{array}{l}\text { 14. Néha észreveszek olyan hangokat is a felvételeken, amik máskor } \\
\text { nincsenek ott. }\end{array}$ & & \\
\hline $\begin{array}{l}\text { 15. Időnként úgy túnik, az idegen emberek kézmozdulatai } \\
\text { befolyásolnak engem. }\end{array}$ & & \\
\hline $\begin{array}{l}\text { 16. Szinte soha nem álmodom meg a dolgokat a megtörténtük előtt. } \\
\text { (R) }\end{array}$ & & \\
\hline $\begin{array}{l}\text { 17. Előfordult már, hogy egy pillanatra úgy éreztem, hogy valaki } \\
\text { helyét egy hasonmása vette át. }\end{array}$ & & \\
\hline $\begin{array}{l}\text { 18. Lehetetlen másokat bántani azáltal, hogy rossz dolgokat } \\
\text { gondolunk róluk. (R) }\end{array}$ & & \\
\hline
\end{tabular}


19. Előfordult már, hogy éreztem a gonosz jelenlétét magam körül, annak ellenére, hogy nem láttam.

20. Néha azt érzem, hogy energiát nyerek vagy vesztek azáltal, hogy bizonyos emberek rám néznek vagy megérintenek.

21. Volt már olyan futó gondolatom, hogy idegen emberek szerelmesek belém.

22. Soha nem éreztem azt, hogy bizonyos gondolataim valójában valaki más gondolatai lennének. (R)

23. Amikor idegeneknek mutatnak be, néha azon túnődöm, vajon találkoztam-e már velük korábban.

24. Ha a reinkarnáció valóban létezne, az sok különös élményemet megmagyarázná.

25. Az emberek gyakran olyan furcsán viselkednek, hogy eltűnődöm vajon nem egy kísérlet résztvevői-e.

26. Néha a negatív hatások elhárítása érdekében bizonyos rituálékat hajtok végre.

27. Éreztem már azt, hogy megtörténtté tehetek valamit pusztán azáltal, hogy túl sokat gondolok rá.

28. Túnődtem már azon, hogy vajon a holtak lelke befolyásolja-e az élőket.

29. Néha megtörtént, hogy azt éreztem az egyetemi elóadáson a professzor szavai külön nekem szólnak.

30. Előfordult néha, hogy azt éreztem, idegenek olvasnak a gondolataimban.

Skálaképzési útmutató:

Az igen válasz 1 pontot, a nem pedig 0 pontot ér.

$\mathrm{R}$ = fordított tétel.

Az eredeti 30 tételes változat esetében az egydimenziós skála pontozása (a fordított tételek megfordítását követóen) a 30 tételre adott válaszok összeadásával történik. Fontos azonban megjegyezni, hogy a 23. tétel az eredeti angol változatban fordított tételként szerepel, de ahogyan arról a fentiekben beszámoltunk, a hazai fordítás során a tétel iránya megfordult, vagyis a magyar változatban ezt a tételt már nem kezeltük fordítottként.

A 15 tételes rövidített változat tételei:

Paranormális hiedelmek alskála: 2., 6., 8., 11., 14., 15., 17. és 25. tétel

Mágikus okság és spiritualitás alskála: 5., 20., 23., 24., 26., 27. és 28. tétel

A skálaképzés (a fordított tételek értékeinek megfordítása után) a hozzájuk tartozó tételek összeadásával történik. 


\title{
Psychometric properties of the Hungarian version of the Magical Ideation Scale (MIS)
}

\author{
RÓZSA, SÁNDOR - VINCZE, GÁBOR - TÖRÖK, IMRE ANDRÁS \\ - HUPUCZI, ERNŐ - HARGITAI, RITA - MARTIN, LÁSZLÓ - \\ HARTUNG, ISTVÁN - TIRINGER, ISTVÁN - SIMON, MÁRIA - \\ KÁLLAI, JÁNOS
}

Background: Study of vulnerability to psychosis and early intervention is an area of great clinical impact and research. The Magical Ideation Scale (MIS) is among the most widely used instruments for the assessment of psychosis proneness. However, there has been little research on the psychometric properties of the MIS in clinical sample. Aims: The main goal of the present work was to study the dimensional structure underlying the MIS in a large sample of students $(n=1.730)$ and clinical subjects $(n=319)$. Methods: The structures of the MIS were examined by confirmatory (e.g., single-factor model, model with second-order factor, bifactor model) and exploratory factor analysis and parallel-analysis. The internal consistencies were calculated not only in the conventional way (e.g. Cronbach's $\alpha$ ) but also in the controlling of the general factor (hierarchical omega, explained common variance). After initial testing, we used Item Response Theory (IRT) to shorten and further refine the instrument, and criterion validity was evaluated by other questionnaires (e.g. Schizotypy Personality Questionnaire - Brief Revised; Interpersonal Reactivity Index). Results: To determine the number of factors that can be applied, parallel-analysis provided a good estimation of the three dimensional structure of MIS in student sample and two dimensions in clinical subjects. However, the reversed worded items caused a method factor that does not appear to be substantively meaningful. Confirmatory factor analysis identified a bifactor solution (general scale and two specific scales: paranormal beliefs and magical reasoning/spirituality) for the MIS in student sample $(\mathrm{RMSEA}=0.052, \mathrm{CFI}=0.993, \mathrm{TLI}=$ 0.990 ), and a unidimensional factor structure in clinical sample (RMSEA $=0.032, \mathrm{CFI}=$ 0.970 , TLI $=0.965$ ). The shortened 15-item version of the MIS has good psychometric properties, but few of the items displayed DIF across gender or type of sample (normative or clinical). Conclusions: Our results confirm that magical ideation can be considered as a single latent psychological variable on clinical sample, and a bifactorial structure in normative sample where the adaptive (magical reasoning/spirituality) and maladaptive (paranormal beliefs) functions separated.

Keywords: Magical Ideation Scale (MIS), magical thinking; paranormal beliefs, confirmatory and exploratory factor analysis, bifactor model, adaptive and maladaptive functions

A cikk a Creative Commons Attribution 4.0 International License (https:/ / creativecommons.org/ licenses/by/4.0/) feltételei szerint publikált Open Access közlemény, melynek szellemében a cikk bármilyen médiumban szabadon felhasználható, megosztható és újraközölhetó, feltéve, hogy az eredeti szerző és a közlés helye, illetve a CC License linkje és az esetlegesen végrehajtott módosítások feltüntetésre kerülnek. (SID_1) 
